NBER WORKING PAPER SERIES

\title{
UNDERSTANDING POLICY IN THE GREAT RECESSION: SOME UNPLEASANT FISCAL ARITHMETIC
}

\author{
John H. Cochrane \\ Working Paper 16087 \\ http://www.nber.org/papers/w16087
NATIONAL BUREAU OF ECONOMIC RESEARCH
1050 Massachusetts Avenue
Cambridge, MA 02138 \\ June 2010
}

I thank Michael Woodford for helpful comments, and Francisco Vaquez-Grande for the surplus plot. I acknowledge research support from CRSP. The views expressed herein are those of the author and do not necessarily reflect the views of the National Bureau of Economic Research.

NBER working papers are circulated for discussion and comment purposes. They have not been peerreviewed or been subject to the review by the NBER Board of Directors that accompanies official NBER publications.

(C) 2010 by John H. Cochrane. All rights reserved. Short sections of text, not to exceed two paragraphs, may be quoted without explicit permission provided that full credit, including $\bigcirc$ notice, is given to the source. 
Understanding Policy in the Great Recession: Some Unpleasant Fiscal Arithmetic

John H. Cochrane

NBER Working Paper No. 16087

June 2010

JEL No. E3,E31,E4,E5,E52,E6

\section{ABSTRACT}

I use the valuation equation of government debt to understand fiscal and monetary policy in and following the great recession of 2008-2009, to think about fiscal pressures on US inflation, and what sequence of events might surround such an inflation. I emphasize that a fiscal inflation can come well before large deficits or monetization are realized, and is likely to come with stagnation rather than a boom.

John H. Cochrane

Booth School of Business

University of Chicago

5807 S. Woodlawn

Chicago, IL 60637

and NBER

john.cochrane@gsb.uchicago.edu

An online appendix is available at:

http://www.nber.org/data-appendix/w16087 


\section{Introduction}

I offer an interpretation of the macroeconomic events in the great recession of 2008-2009, and the subsequent outlook, focused on the fiscal stance of the U. S. government and its link to potential inflation. What happened? How did policies work? Are we headed for inflation or deflation? Will the Fed be able to follow an "exit strategy?" Will large government deficits lead to inflation? If so, what will that event look like?

I base the analysis on two equilibrium conditions, some form of which hold in almost every model of money and inflation: the valuation equation for nominal government debt and a money demand equation,

$$
\begin{aligned}
\frac{M_{t}+B_{t}}{P_{t}} & =E_{t} \int_{\tau=0}^{\infty} \frac{\Lambda_{t+\tau}}{\Lambda_{t}}\left(T_{t+\tau}-G_{t+\tau}\right) d \tau \\
M_{t} V\left(i_{t}, \cdot\right) & =P_{t} Y_{t}
\end{aligned}
$$

where $M$ is money, $B$ is debt, $\Lambda$ is a stochastic discount factor, $T$ is tax revenue including seigniorage, and $G$ is government spending. Sargent and Wallace (1981) (also Sargent 1992) used these two equations to analyze disinflation in the 1980s. I follow a similar path.

Monetary economists studying the postwar U.S. typically do not pay much attention to fiscal issues, feeling with some justification that fiscal issues are not a serious constraint to monetary policy. But these are new times, with massive fiscal deficits, credit guarantees, and Federal Reserve purchases of risky private assets. At some point (rises in $B_{t}$, declines in $T_{\tau}-G_{\tau}$ ) fiscal constraints must take hold. There is a limit to how much taxes a government can raise, a top of a Laffer curve, a fiscal limit to monetary policy. At that point, inflation must result, no matter how valiantly the central bank attempts to split government liabilities between money and bonds. Long before that point, the government may choose to inflate rather than further raise distorting taxes or reduce politically important spending. Argentina has found these fiscal limits. So far, the U. S. has not, at least recently. But unfamiliarity does not mean impossibility, the future may be different from the recent past, and fiscal constraints may change how monetary policy and inflation work.

After a quick review of the theory underlying the fiscal equation, I analyze the current situation, common forecasts, and policy debates. I make the following points:

1. Why did a financial crisis lead to such a big recession? We understand how a surge in money demand, if not accommodated by the Fed, can lead to a decline in output. I argue that we saw something similar - a "flight to quality," a surge in the demand for all government debt and away from goods, services and private debt. In the fiscal context of (1), this event corresponds to a decrease in the discount rate for government debt. Many of the Government's policies can be understood as ways to accommodate this demand, which a conventional swap of money for government debt does not address. This story is in contrast to "lending channel" or "financial frictions" stories for the recession, essentially falls in aggregate supply.

2. Winter 2009 saw the announcement of dramatic fiscal stimulus programs in the U. S., U. K., and many other countries, along with academic controversy over their effectiveness. 
(a) Will "fiscal stimulus" stimulate? In this analysis, deficits "stimulate" if and only if people do not expect future taxes to pay off the increased debt. Unlike conventional "Ricardian equivalence," we do not need irrationality or market failure for this expectation, since our government debt is nominal.

(b) Much stimulus debate revolves around the fact that fiscal expenditures cannot happen quickly. In this analysis, prospective deficits are just as "stimulative" as current deficits.

3. With interest rates near zero, monetary policy turned to quantitative easing: large additional purchases of government debt. I show that quantitative easing cannot inflate without fiscal cooperation. If the government wants inflationary stimulus, it must somehow convince people that the government will not raise taxes or cut spending to pay off deficits. If people expect extra money to be soaked up by later taxes, they are happy simply to hold it.

4. I examine the mechanisms and scenarios that could bring us inflation.

(a) Can the Fed undo the massive money expansion with open market purchases, or will it be hard to sell trillions of additional Treasury bills? The fiscal analysis does not suggest substantial impediments. If quantitative easing makes little difference on the way up, it is easy to reverse on the way down. If inflation comes, then, it is more likely to result from the fiscal mechanism.

(b) What will a fiscal inflation look like? I extend the simple fiscal equation (1) to longterm debt, and I analyze a stylized shock to expected surpluses. In a plausible scenario, long-term interest rates rise with the shock, but inflation only comes slowly after a few years.

(c) Credit guarantees and nominal commitments to government employees make matters worse than actual deficits suggest. On the other hand, they imply that a smaller inflation has a larger effect on government finances.

(d) If taxes have any effect on growth, the 'Laffer limit' of taxation may come much sooner than static analysis suggests. The present value of taxes is strongly influenced by growth. The big inflation danger is a long period of slow growth.

(e) Many commentators argue that fiscal inflation is remote, since the US debt/GDP ratio is still reasonable. Since prospective deficits matter in (1), I point out that debt/GDP ratios are not a good guide to fiscal safety.

5. Last, but perhaps most important: Will a fiscal inflation come with a boom or stagflation? I argue that the fiscal valuation equation acts as the "anchor" for monetary policy, or the "expectation" that shifts the Phillips curve. A fiscal inflation is therefore likely to lead to the same stagflationary effects as any loss of "anchoring."

I focus on equations (1) and (2) because they are common to a wide array of fully fleshed-out models. It is also nice to see that we can begin to understand many events in their relatively frictionless context. However, equations (1) and (2) are the beginning, 
not the end of analysis, and I do not mean to imply otherwise. In particular, monetary models also include a description of dynamics, and price-stickiness or other mechanism that sometimes translates inflation into real output, which I only touch on at the end of this essay. Additional frictions, to consider stimulative effects of tax or real debt-financed government spending, and additional financial frictions can easily be added to this style of analysis.

\section{Fiscal review}

\subsection{The government debt valuation equation}

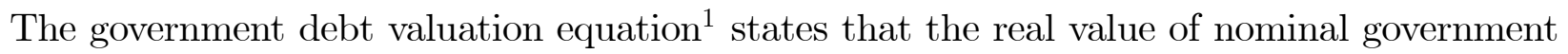
debt must equal the present value of future primary surpluses. In the simplest case that the government issues floating-rate or overnight debt, it reads

$$
\frac{M_{t}+B_{t}}{P_{t}}=E_{t} \int_{\tau=0}^{\infty} \frac{\Lambda_{t+\tau}}{\Lambda_{t}}\left(s_{t+\tau}+i_{t+\tau} \frac{M_{t+\tau}}{P_{t+\tau}}\right) d \tau
$$

where $M_{t}$ is money, $B_{t}$ is government debt, $\Lambda_{t+\tau} / \Lambda_{t}$ is the real stochastic discount factor between periods $t$ and $t+\tau, i_{t}$ is the nominal interest rate and $s_{t}=T_{t}-G_{t}$ denotes real primary surpluses. The web appendix (Cochrane 2010) derives this and related equations. In particular, it explains that we can also discount at the ex-post real rate of return on government debt, i.e. we may substitute $1 / R_{t, t+\tau}$ for $\Lambda_{t+\tau} / \Lambda_{t}$, which is useful for thinking about discount-rate effects more concretely. Seigniorage $i_{t} M_{t} / P_{t}$ is small for the U. S. economy, and I will ignore it in most application and discussion.

The description of price-level determination in (3) is not unusual or counterintuitive. If, at the current price level, the real value of government debt is greater than expected future surpluses, people try to get rid of that debt and purchase private assets and goods and services instead. This is "aggregate demand" or a "wealth effect of government debt."

Our most pressing question is, how might debt and deficits translate into inflation? Equation (3) gives an unusual answer and a warning: Expected future deficits $s_{t+j}$ cause inflation today. Inflation need not wait for large deficits to materialize, for large debt to GDP ratios to occur, for monetization of debt or for explicit seigniorage. As soon as people figure out that there will be inflation in the future, they try to get rid of money and government debt now.

More specifically, the flow version of (3) says that the government prints money to redeem maturing debt, and then soaks up that money with current surpluses and by issuing new debt. If expected future surpluses decline, then people forecast future inflation, when those deficits really are directly monetized. Nominal interest rates rise, and hence the government raises less revenue from today's debt sales. Now, the new money used to redeem maturing debt today is no longer all soaked up by current surpluses or new debt sales. (Selling more debt today won't help, because that requires raising promised future surpluses.) Instead,

\footnotetext{
${ }^{1}$ Many of the points in this section are treated at more length in Cochrane (1998), (2001), (2005). These papers also contain bibliographic reviews, which more properly attribute credit for the ideas.
} 
that money must chase goods and services. In this way, difficulties in rolling over short-term debt in the face of higher interest rates are one of the first signs of a fiscal inflation driven by expected future deficits, and a central mechanism by which future deficits induce current inflation. A rise in the discount rate or risk premium for government debt can have the same inflationary impact as bad news about future surpluses.

One might well ask, "What surpluses?" as the U.S. has reported continual deficits for a long time. However, equation (3) refers to primary surpluses, i.e. net of interest expense. Figure 1 presents a simple estimate of the primary surplus, taken from the NIPA accounts, and expressed as a percentage of GDP. In fact, positive primary surpluses are not rare. From the end of the second world war until the early 1970s, the US typically ran primary surpluses, and paid off much of the WWII debt in that way. 1973 and especially 1975 were years of really bad primary deficits, on the tail of a downward trend, and suggestively coinciding with the outbreak of inflation. The "Reagan deficits" of the early 1980s don't show up much, especially controlling for the natural business cycle correlation, because much of those deficits consisted of very high interest payments on a stock of outstanding debt. The return to surpluses in the late 80s and the strong surpluses of the 1990s are familiar, and suggestively correlated with the end of inflation. Our current situation resembles a cliff, motivating some of the concerns of this paper.

Though suggestive, the association of primary surpluses with the emergence and end of inflation in Figure 1 requires a subtle analysis. Equation (3) holds in every macroeconomic model, both ex-ante and ex-post, so success in such matching is in some sense guaranteed, especially once one takes into account the rate of return on government debt. In any workedout model, current surpluses are a bad indicator of the present value of future surpluses, as governments raise debt (run deficits) by credibly promising higher future surpluses.

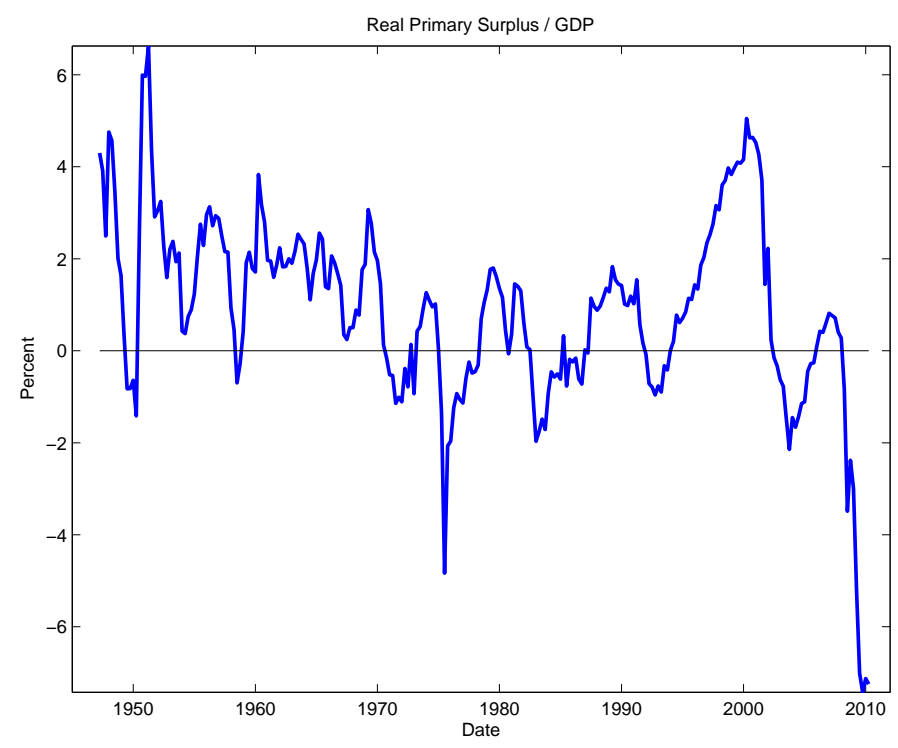

Figure 1: Real primary surplus/GDP. Primary surplus is current receipts - current expenditures + interests expense, deflated with the GDP deflator. Source: NIPA. 


\subsection{Monetary and fiscal policy}

To capture the idea that monetary policy can affect the price level by the split of government liabilities between money and debt, we also need a money demand function, that captures the "special" nature of money,

$$
\left(M_{t}+M_{t}^{i}\right) V\left(i_{t}, \cdot\right)=P_{t} Y_{t} .
$$

The notation $\left(i_{t}, \cdot\right)$ reminds us that many variables can affect velocity as well as interest rates; "precautionary" or "flight to quality" shifts in money demand. I include $M^{i}$ because money demand theories typically predict that inside money $M^{i}$ (checking deposits) matter as well as the monetary base, direct government liabilities $M_{t}$.

Equations (3) and (4) each involve the price level. Thus, government must arrive at a "coordinated policy" by which monetary and fiscal policy agree on that price level, a choice of $\left\{M_{t}, B_{t}, s_{t}\right\}$ (and controls on $M^{i}$; or equivalent interest-rate policy) such that both (3) and (4) hold. Successful monetary policy needs an appropriate fiscal backing; successful fiscal expansion needs monetary cooperation.

Conventional treatments of monetary policy specify that the taxing authorities will always adjust surpluses $s_{t+j}$ ex-post to validate any price level chosen by monetary authorities through (4), thus assuming away any force for (3). We're here to think about what happens when (3) exerts more force on the price level. This may happen when debt, deficits and distorting taxes become large, or by choice, when monetary regimes become passive.

The government debt valuation equation (3) influences the price level in some unusual ways, that contrast with many classic monetary doctrines. First, except for the small seigniorage term $\left(i_{t} M_{t} / P_{t}\right)$, there is no difference between money and bonds in (3), so open market operations have no effects on the price level. Second, only government money and debt matter for the price level. People can generate arbitrary inside claims $M^{i}$ with no inflationary pressure, and the government need not control such claims - ban banknotes, require reserves, etc. - in order to control the price level. In fact, the price level can remain determined even at the frictionless limit, say with all transactions mediated by debit cards on interest-paying funds, $M_{t}=0$, or with money that pays market interest. Third, the government can follow a real-bills doctrine: If the government issues money $M$ or debt $B$ in exchange for assets of equal value, which can retire that debt in time, no inflation results. The price level also remains determinate with an interest-rate peg, or other "passive money" policies.

We do not have to specify how monetary-fiscal coordination is achieved. We do not have to make a choice or diagnosis of "regime." We need not argue what is "exogenous" or "endogenous." In particular, analyzing equation (3) does not require us to assume that surpluses are "exogenous" in any sense. Surpluses are always a choice, though one that involves distorting taxes and politically difficult spending decisions. Studying events conditional on such decisions does not assume that those decisions do not exist. We are never "choosing which equation holds." Both (3) and (4) hold in every equilibrium or regime. Our question is, how? Even one thinks the Fed is in charge of the price level through (4), and Congress and the Treasury pledge to respond with the appropriate surpluses in (3), it's useful to examine that implicit fiscal backing to see if it is vaguely plausible that it will or can be provided. 


\subsection{Sargent, Wallace, seigniorage and nominal debt}

My analysis of (3) and (4) differs from Sargent and Wallace's (1982) and many other joint fiscal-monetary analyses, in that I explicitly consider nominal government debt - debt is only a promise to pay U.S. dollars.

To see the importance of nominal vs. real debt, we can rewrite (3) (see the Appendix) as

$$
\frac{B_{t}}{P_{t}}=E_{t} \int_{\tau=0}^{\infty} \frac{\Lambda_{t+\tau}}{\Lambda_{t}}\left(T_{t+\tau}-G_{t+\tau}+\frac{d M_{t+\tau}}{P_{t+\tau}}\right) d \tau,
$$

counting seigniorage by money creation rather than interest savings. With real debt, this equation reads

$$
b_{t}=E_{t} \int_{\tau=0}^{\infty} \frac{\Lambda_{t+\tau}}{\Lambda_{t}}\left(T_{t+\tau}-G_{t+\tau}+\frac{d M_{t+\tau}}{P_{t+\tau}}\right) d \tau,
$$

where $b_{t}$ denotes the real amount of debt, which does not change if the price level changes.

Sargent and Wallace, examining (6), argued that looming $T_{t+\tau}-G_{t+\tau}$ problems would have to be met by seigniorage, $d M_{t+\tau} / P_{t+\tau}$. That money creation, through $M_{t+\tau} V(\cdot)=$ $P_{t+\tau} Y_{t+\tau}$ would create inflation at time $t+\tau$. Finally, that future inflation could be brought back to the present time $t$ by hyperinflation dynamics $M_{t} V\left[E_{t}\left(d P_{t} / P_{t}\right)\right]=P_{t} Y_{t}$.

With nominal debt, as in (5), inadequate future $T_{t+\tau}-G_{t+\tau}$ can raise the current price level $P_{t}$ directly. This rise lowers the outstanding value of nominal government debt, reestablishing equation (5). This channel is absent with real debt. (State-contingent debt or an explicit default can also accomplish such a revaluation, but Sargent and Wallace sensibly assumed that the U.S. government would inflate rather than explicitly default.)

Most commentators assume that inflation can only come after money creation, whether induced by seigniorage needs or by policy mistakes. In fact, with nominal debt, not only can inflation come before the seigniorage, as pointed out by Sargent and Wallace, it can come without any current or past money creation ${ }^{2}$ at all, $d M=0$ in (5). A fiscal or "flight from the dollar" inflation can occur based directly on expectations of future fiscal trouble.

Nominal debt works like equity: its price can absorb shocks to expected future cashflows, and its price reflects expectations of future events. Real debt works like debt, which must be repaid or explicitly default. There is sense in the view that exchange rates and inflation reflect "confidence" in the government, output, productivity and fiscal prospects, all having nothing to do with central banks' arrangement of the maturity and liquidity structure of government debt.

\footnotetext{
${ }^{2} \mathrm{~A}$ clarification: $M$ here refers to money, held despite an interest cost. In a frictionless model, inflation still comes from "monetization," in the sense that the government prints money to pay off debt, larger than is soaked up by taxes and debt sales if the price level is too low. This extra money then puts upward pressure on prices. In the frictionless limit, this happens instantaneously, and nobody holds any dominated-rate-of-return debt overnight, so there is no seignorage.
} 


\subsection{Long term debt and inflation dynamics}

Equation (3) describes the simple case of floating-rate or overnight debt. The dynamic relationship between debt, surpluses and inflation can be quite different with long-term debt. These differences are important to understand, in order to apply these ideas to the U. S. economy. In particular, they suggest that a fiscal inflation will not consist of price-level jumps, and fiscal price determination does not mean that the price level must display the volatility and unpredictability of stock prices. Instead, fiscal inflation will likely consist of a smooth increase in inflation presaged by higher long-term interest rates.

As an extreme but simple example, suppose that debt consists of a single perpetuity: A constant coupon $c$ is redeemed each period, with no other debt purchases or sales and no money. In this case, the price level is the ratio of the nominal coupon coming due each period to the real surpluses that can redeem it,

$$
\frac{c}{P_{t}}=s_{t}
$$

In this case, inflation only happens when the actual poor surpluses $s_{t+j}$ are realized, and not in anticipation of those surpluses as in (3) or (5).

With long-term debt, the present-value equation (3) still holds, in the form

$$
\frac{B_{t}}{P_{t}}=\frac{\int_{j=0}^{\infty} Q_{t}^{(j)} B_{t}^{(j)} d j}{P_{t}}=E_{t} \int_{\tau=0}^{\infty} \frac{\Lambda_{t+\tau}}{\Lambda_{t}} s_{t+\tau} d \tau,
$$

(again, simplifying to no money), where $B_{t}=\int_{j=0}^{\infty} Q_{t}^{(j)} B_{t}^{(j)} d j$ denotes the market value of nominal government debt, $B_{t}^{(j)}$ denotes maturity $j$ debt and

$$
Q_{t}^{(j)}=E_{t}\left(\frac{\Lambda_{t+j} P_{t}}{\Lambda_{t} P_{t+j}}\right)
$$

denotes the nominal price at $t$ of $j$-year debt. With long -term debt, the market value of debt as well as the price level can absorb expected-surplus shocks. In the extreme perpetuity example (7), bad news about a future surplus $s_{t+j}$ raises only the future price level $P_{t+j}$. Future inflation lowers bond prices $Q_{t}^{(j)}$, so bond prices in the numerator of (8) do all the adjusting at $t$ rather than time-t prices $P_{t}$ in the dominator. In general, both effects will occur.

With long-term debt, the government can also trade current for future inflation, holding fixed the surplus stream, by selling additional long-term debt. This new debt dilutes the claims of existing long-term debt, giving the government some resources to avoid current inflation. However, by increasing the stock of long-term debt it makes the eventual inflation worse. By contrast, with floating-rate or overnight debt, the government can still freely choose the future price level $\left\{P_{t+j}\right\}$, with no change in surpluses, by changing $B_{t+j}$. Changing nominal debt without changing surpluses is the same thing as a currency reform. However, this action does not affect the current price level $P_{t}$, as you can see in (3).

The maturity structure of outstanding long-term debt gives the "budget constraint" to the government's options for trading inflation today for inflation at future dates by such 
surplus-neutral debt sales and purchases. This statement is easiest to digest in the case of a constant real rate so $\Lambda_{t}=e^{-r t} \Lambda_{t}$. Then (8) reads

$$
\int_{j=0}^{\infty} E_{t}\left(\frac{1}{P_{t+j}}\right) e^{-r j} B_{t}^{(j)} d j=E_{t} \int_{\tau=0}^{\infty} e^{-r \tau} s_{t+\tau} d \tau .
$$

By buying and selling debt at date $t$ and later, after $E_{t} s_{t+\tau}$ is revealed, the government can achieve any sequence $E_{t}\left(1 / P_{t+j}\right)$, consistent with this equation, without making any changes in surpluses. The more long-term debt outstanding - the greater $B_{t}^{(j)}$ relative to $B_{t}^{(0)}$ - the better the tradeoff. (For a proof, see Cochrane 2001 p. 88).

\subsection{An inflation scenario}

How will inflation react to a negative shock in expected surpluses? This is our central question. To answer this question, we have to measure the maturity structure of outstanding debt, and take a stand on how the government will attempt to smooth inflation via debt sales, as follows.

If the U.S. only had overnight or floating-rate debt, the answer would be simple: A sudden change in expectations about the present value of future surpluses implies a jump in the price level $P_{t}$, by (3). The government can choose any path $\left\{E_{t}\left(1 / P_{t+j}\right)\right\}$ after that, by appropriately choosing the path of nominal debt, and it might well choose no additional inflation. However, long-term debt allows the government to avoid price-level jumps. Pricelevel jumps are not desirable either, and that may be a good reason why our government issues long-term debt.

Suppose that the economy starts at a steady-state price level $P$, and there is a single expected-surplus shock $\Delta S_{t}$ at date $t$,

$$
\Delta S_{t} \equiv\left(E_{t}-E_{t-\Delta}\right) \int_{\tau=0}^{\infty} e^{-r \tau} s_{t+\tau} d \tau
$$

With long-term debt from (9), the subsequent price level paths $\left\{P_{t+j}\right\}$ must satisfy

$$
\int_{j=0}^{\infty} e^{-r j}\left(\frac{1}{P_{t+j}}-\frac{1}{P}\right) B_{t}^{(j)} d j=\Delta S_{t} .
$$

We can rewrite this condition in a convenient dimensionless form as

$$
\int_{j=0}^{\infty}\left(\frac{\frac{1}{P_{t+j}}-\frac{1}{P}}{\frac{1}{P}}\right) W_{t}^{(j)} d j=\frac{\Delta S_{t}}{S}
$$

where

$$
W_{t}^{(j)} \equiv \frac{e^{-r j} B_{t}^{(j)}}{\int_{j=0}^{\infty} e^{-r j} B_{t}^{(j)} d j}
$$

denotes the fraction of the market value of debt due to maturity-j debt. 
Holding the path of surpluses constant, the government can still choose any path $\left\{P_{t+j}\right\}$ consistent with (10). With outstanding long-term debt $W_{t}^{(j)}>0$, the government can trade less inflation now $P_{t}$ for more inflation later $P_{t+j}$. To display the response to a surplus shock, then, we have to take a stance on which path the government will choose. Our government seems to prefer steady inflation to highly variable inflation or price level jumps, and for good reasons. To get a sense of the possibilities, I suppose the government holds inflation to zero for $\mathrm{T}$ years, and then allows a constant inflation $\pi_{T}$,

$$
\begin{aligned}
& P_{t+j}=P ; \quad j<T \\
& P_{t+j}=P e^{\pi_{T}(t-j)} ; j \geq T .
\end{aligned}
$$

To find the required inflation $\pi_{T}$ for a given surplus shock $\Delta S_{t}$, we must have

$$
\int_{j=T}^{\infty}\left(\frac{1}{e^{\pi_{T}(j-T)}}-1\right) W_{t}^{(j)} d j=\frac{\Delta S_{t}}{S} .
$$

II suppose a $10 \%$ negative shock to the present value of expected surpluses, $\Delta S_{t}=-10 \%$. I form an estimate of the maturity structure of outstanding debt $W_{t}^{(j)}$. Then, for each $T, \mathrm{I}$ find the value of $\pi_{T}$ that solves equation (11).

To estimate the maturity structure $W_{t}^{(j)}$, I use every bond, bill, or note in the CRSP mbx database on Jan 31, 2009. I assign coupons to the month in which they come due, so $B_{t}^{(j)}$ includes both principal and coupon payments coming due at time $t+j$. This is a very crude measure: I do not include Federal Reserve liabilities, nor offsetting government or Federal Reserve assets. I do not include credit guarantees, nor the nominal value of unused depreciation allowances and other nominal commitments. I do not include nominally-sticky salaries and pension or health benefits of government workers. However, this is a useful starting place. It lets us begin to think about how much of a long-term debt cushion the U.S. government has, and thus how quickly surplus shocks must feed in to inflation.

Figure 2 plots three possibilities. First, I plot (red triangles) a one-time $11 \%$ price-level jump. This is the solution with no long-term debt, and it remains available in the presence of long-term debt; it is a solution of (10).

Next, I plot (blue circles) a steady $2.75 \%$ inflation starting immediately $\left(\pi_{T}, T=0\right)$. This is a much more plausible path. To arrange it, the government sells long-term debt to meet the surplus shock. This inflation path soon brings about higher future price levels than the one-time jump, which is how it still satisfies (10).

Finally, I plot (black triangles) a postponed inflation. Here, the government sells even more long term debt immediately, so as to have no inflation at all for four years. In the fifth year, it allows the necessary inflation to emerge. Since there isn't that much long-term debt outstanding at this maturity, the resulting inflation and cumulative price-level increases are also much larger.

Again, the government can choose which one of these paths to follow, with no difference in surpluses, by its long-term debt operations. Which one will our government choose? Certainly not the price level jump. The delayed-inflation scenario seems plausible to me. 

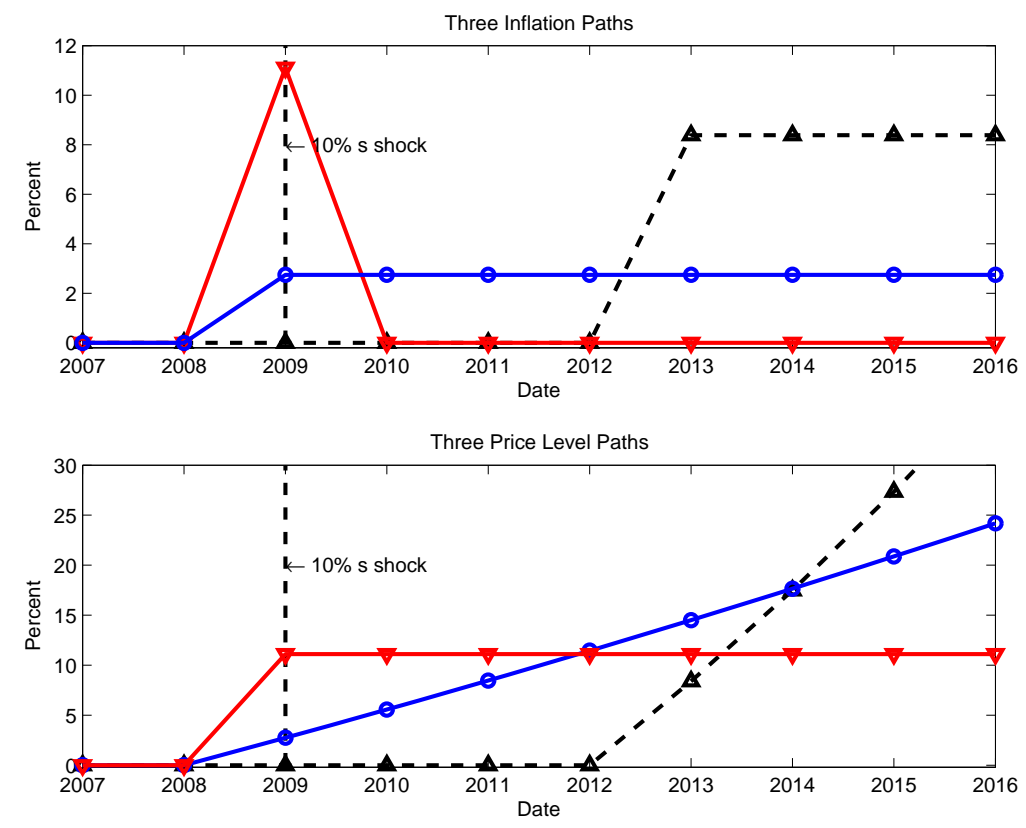

Figure 2: Three possible reactions to a $10 \%$ expected surpluse shock $\Delta S_{t}=$ $\left(E_{t}-E_{t-\Delta}\right) \int_{\tau=0}^{\infty} e^{-r \tau} s_{t+\tau} d \tau$. Red triangles display a time-t price level jump followed by no additional inflation. Blue circles display a steady inflation starting at time t. Black triangles display a steady inflation starting 4 years after the shock. The choices are calibrated to an estimate of the US Federal debt maturity structure.

(Of course, one could try to estimate this behavior, or solve an optimal inflation-smoothing exercise after adding some frictions, but either is a lengthy exercise.)

To further bring the postponed-inflation possibility to life, Figure 3 plots the corresponding time series of inflation and bond yields. The vertical line indicates the date of the surplus shock. First, long term bond yields rise. As the inflation approaches, shorter term rates rise as well. Finally, 5 years after the surplus shock, the steady inflation actually materializes.

When you think of fiscal inflation, then, think at least of this possibility, not a price-level jump. The "news" here is a collective decision by investors that the US is likely not to solve its long-term deficit problems, or a rise in the discount rate applied to U.S. debt. Such "news" is seldom independently visible. Thus, we are likely first to see a puzzling rise in longterm interest rates. Shorter rates will follow, and steady inflation will follow that, on a on a time scale roughly coincident with the average maturity of government debt. The longer the government puts off the inevitable inflation, the larger the cumulative price increase must be. Price stickiness or other frictions can further smooth inflation. In section 16 below, I consider the output consequences of this inflation path in a standard New-Keynesian model. Since the inflation is expected, the inflationary episode corresponds to low output, to "stagflation" or an adverse Phillips curve shift, not to a boom or movement along that curve.

In sum, long-term debt changes the dynamics substantially. However, the simple floating- 


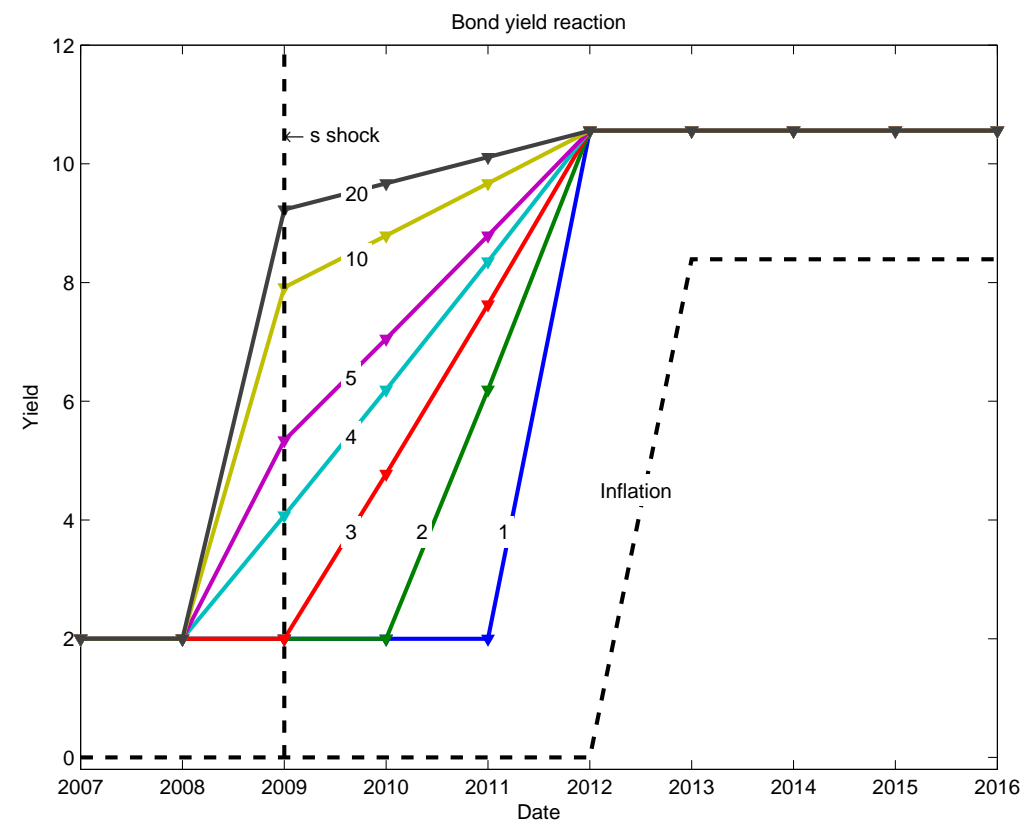

Figure 3: Bond yields and inflation, from a $10 \%$ shock to expected surpluses $\Delta S$, when the government sells debt to postpone inflation for 5 years. Numbers indicate the maturity of the bond yields. The vertical line indicates the date of the surplus shock. I assume a $2 \%$ constant real rate.

rate case remains a useful guide, if we remember to apply it on a scale of several years, and I will do that in the following discussion.

\section{The great recession, and "more of both" policy}

With this conceptual framework in mind, we can examine the events of the great recession, try to understand policy actions, and speculate about the future.

The first issue is, why was there such a large fall in output? For once in macroeconomics we actually know exactly what the shock was - there was a "run" in the shadow banking system (See for example Gorton and Metrick, 2009b, or Duffie, 2010). But how did this shock propagate to such a large recession?

We have long understood that a sharp precautionary increase in money demand, if not met by money supply, would lead to a decline in aggregate demand. With price-stickiness or dispersed information, a decline in aggregate demand can express itself as a decline in real output rather than a decline in the price level. This is in essence Friedman and Schwartz's explanation for the great depression. However, this story cannot credibly apply to the 20082009 recession. The Federal Reserve flooded the country with money (reserves). There is no evidence for a flight to money at the expense of government bonds. There was no run on commercial banks as in the great depression; in fact bank deposits increased substantially. 
There is instead evidence for a broader "flight to quality," a flight to all government debt at the expense of private debt and goods and services. In the fiscal analysis of (3), this is a decline in the discount rate for government debt, which lowers aggregate demand. We also can interpret many actions by the US and other governments as efforts to exchange government debt for private debt to satisfy that demand, as Friedman and Schwartz would have had them exchange government debt for money.

This analysis may seem conservative; it rehabilitates a view of the recession close to a standard monetary one, based on a notion of "aggregate demand" with real effects, rather than focusing on a "lending channel" or other credit frictions. However, it is also novel, since demand and supply of all government debt take center stage, not demand and supply for money.

\subsection{Money supply and demand}

To evaluate money supply and demand, Figure 4 shows the behavior of the Federal Funds and 3 month Treasury bill rates. Figure 5 presents M1, currency and deposits, and Figure 6 describes Federal Reserve assets and liabilities

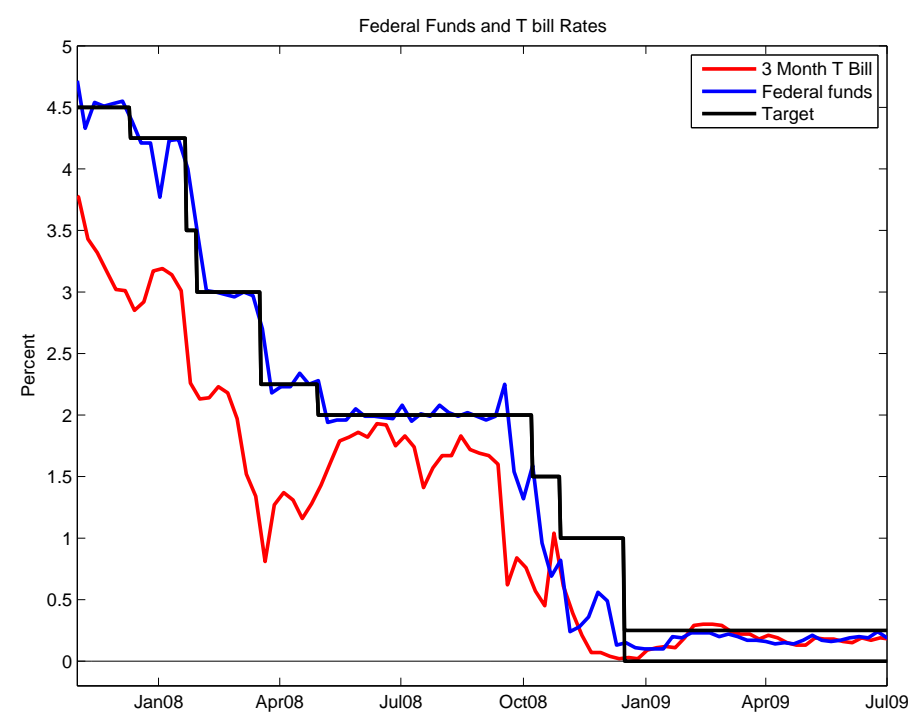

Figure 4: Federal Funds and 3 month Treasury bill rates

As the financial crisis took off in the third week of September 2008, the Federal reserve swiftly cut the Federal Funds target to a range between 0 and $25 \mathrm{bp}$, and signaled it would leave interest rates there for a long time (Figure 4). Inflation declined, never turned to deflation so real rates on these assets remained near zero. M1, currency and deposits, standard measures of money all increased substantially, shown in Figure 5. M1 rose $\$ 250 \mathrm{~b}$, currency rose $\$ 100 \mathrm{~b}$ and deposits spiked to $\$ 200 \mathrm{~b}$ and leveled off about $\$ 120 \mathrm{~b}$. In percentage terms, currency rose $15 \%$ and M1 rose 20\%, all despite a fall in GDP. The expansion of 

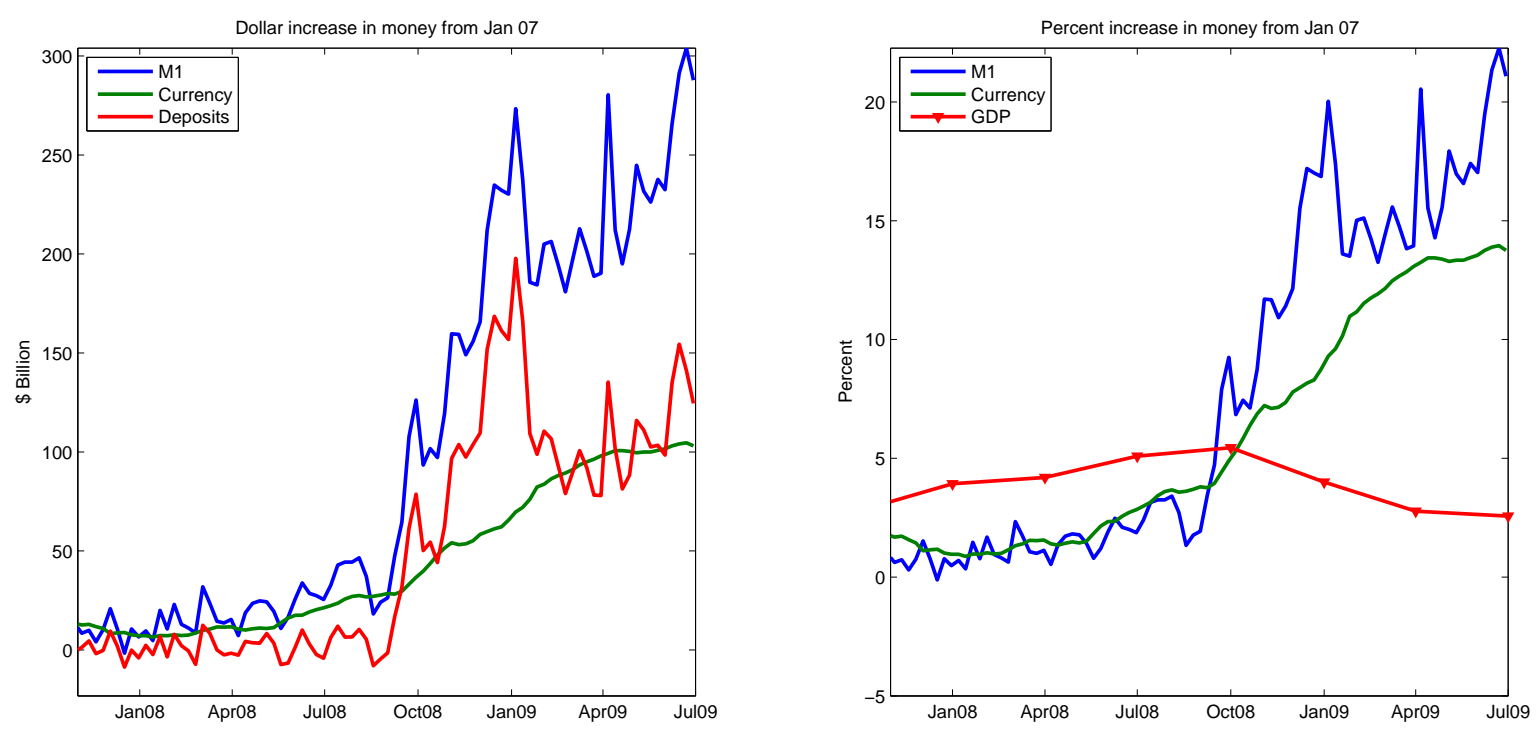

Figure 5: Money stock
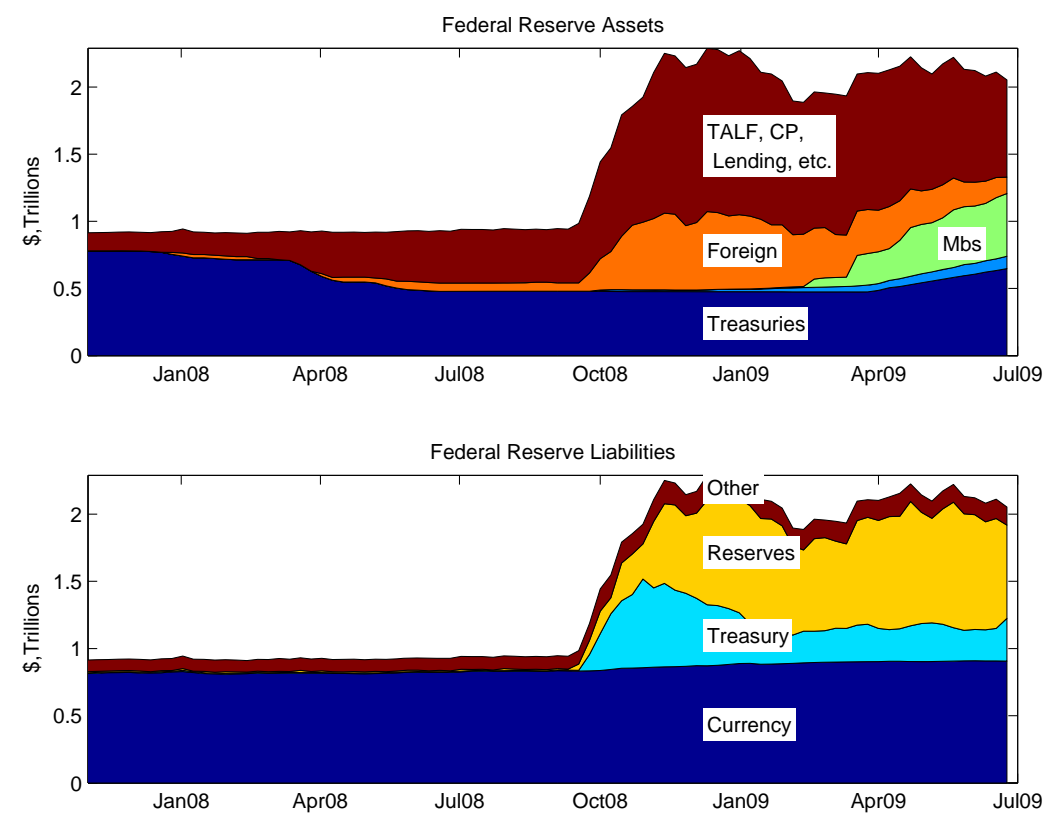

Figure 6: Federal reserve assets and liablilities. Source: Federal Reserve H.4.1 release, June $25,2009$.

the Fed's balance sheet in Figure 6 is the most dramatic. Excess reserves rose from $\$ 6 \mathrm{~b}$ to $\$ 800 \mathrm{~b}$. While it's hard to disprove anything in economics, it certainly seems an uphill battle to argue that the recession resulted from a failure by the Fed to accommodate shifts in money demand. 


\subsection{More of both; aggregate demand}

Conventional monetary policy only trades money for government debt. It considers demand for more money and less government debt, and policy that controls this split. The events of the great recession suggest a large increase in demand for both money and government debt. All government bond interest rates declined sharply. Dramatic credit spreads opened. For example, high rated tax-free municipal bonds (including those issued by universities such as Harvard and Chicago) sold above treasuries. A large liquidity spread opened up between on-the-run and off-the-run government issues. The dollar rose, putting a dramatic end to the "carry trade."

Figure 7 presents some of this evidence. You can see the rise in credit and term spreads. Baa and Aaa rates rise, while the 3 month Treasury Bill rate declines; it was below the Federal funds rate and even briefly negative as shown in Figure $4 ; 3$ month nonfinancial commercial paper does not change much but financial paper rises sharply. The Fed's major currencies index rose from 74.1 on Sept 22, to 82.0 on Nov. 3, a $10.6 \%$ rise, while the stock market was crashing.

Quantities are harder to document than prices but reports were dramatic of markets that "froze up" - issuers were unwilling to suffer these rates. And this is all despite strong efforts by the Fed. These events suggest a "flight to quality" or "flight to liquidity" from private assets to U. S. debt of all maturities.

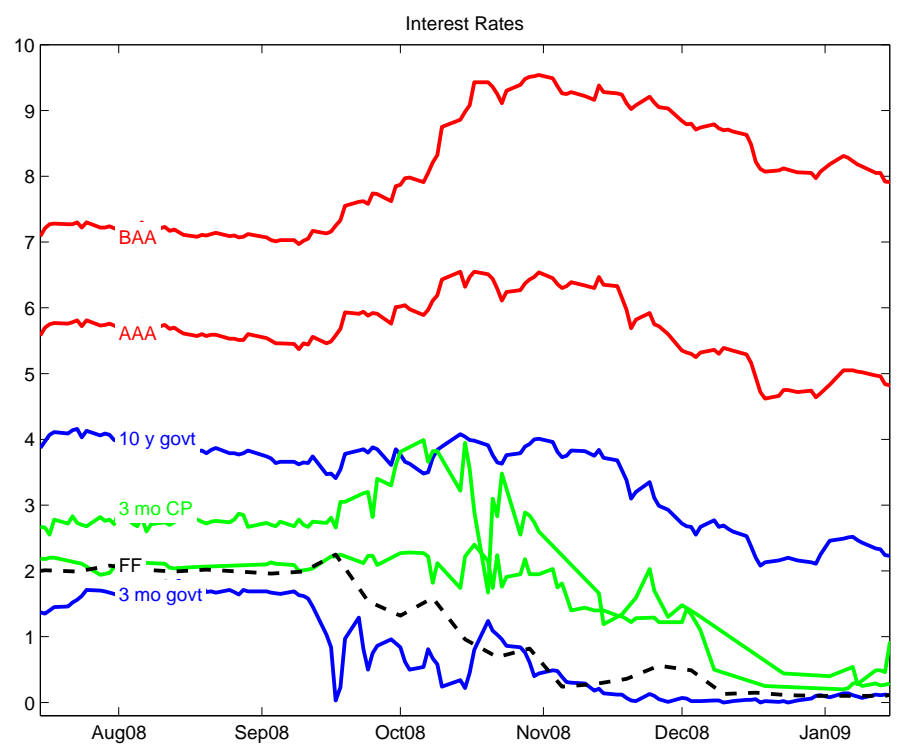

Figure 7: Interest rates. Moody's BAA and AAA; 10 year Treasury constant maturity and 3 month Treasury bill; 3 month nonfinancial and financial commercial paper

As one micro motivation for the flight, government bonds became practically the only security one could easily repo. (Gorton and Metrick 2009). In normal times, if you own a corporate bond or a mortgage-backed security, you can sell it in a repurchase agreement or use 
it as collateral for a loan, thus financing the bond purchase. In the Fall of 2008, suddenly the collateral requirements increased dramatically. A government bond was as good as a dollar to a large, cash-strapped financial institution, because if you had a government bond, you could borrow a dollar.

The combination of near-zero government rates and reserves paying interest, means that the distinction between government bonds and money (reserves) was a third-order issue for financial institutions, especially compared to the very high interest rates, lack of collateralizability, and illiquidity of any instrument that carried a whiff of credit risk. If they wanted more of either, they wanted more of both.

In short, something like the "special" or "liquidity" services we usually associate with money applied to all government debt for these central actors. Those services were related to liquidity, transparency on balance sheets, acceptability as collateral, and absolute security of nominal repayment, rather than the acceptability as means of payment in transactions that we usually emphasize in money-demand theories.

$M V(\cdot)=P Y$ does not allow us to address a "flight to quality" of this this sort. We can understand it in the fiscal framework, however, since that framework treats $M$ and $B$ symmetrically. A sudden demand for government debt, with no (good) news about surpluses, means that people are willing to hold that debt despite dramatically lower rates of return. (Analogously, a sudden precautionary increase in money demand means people are willing to hold money despite an increase in the interest rate, i.e. a lower relative rate of return for money holding.) In our fiscal framework,

$$
\frac{M_{t}+B_{t}}{P_{t}}=E_{t} \int_{\tau=0}^{\infty} \frac{1}{R_{t, t+\tau}} s_{t+\tau} d \tau,
$$

a lower discount rate $R_{t, t+\tau}$ raises the right hand side, and lowers aggregate demand on the left. People want to hold more $M$ and $B$, while holding less private debt and less goods and services.

(For the moment, I will not be specific about the mechanism by which a decline in "aggregate demand" corresponds to a decline in output vs. prices. I'll look at the simple monetary and fiscal equations, think about inflationary and deflationary scenarios, and allow some of that pressure to be reflected in output rather than prices. I return to this question below.)

This analysis can apply more generally. First, it gives a new sense of the "reserve currency" nature of the dollar. In "flight to quality" episodes, people seem to flock to U.S. debt, sending down long-term interest rates. The "reserve" aspect of the dollar is that foreign central banks and other institutions hold a lot of U.S. debt, much of it long-term, and use this as backing for their own currencies. Arguably, the U.S. has financed a good deal of trade surplus by this one-time rise in U.S. debt holdings by foreigners, much as a government might benefit from seigniorage resulting from wider adoption of its currency. All of these observations apply to debt as well as money, not to U.S. currency; the extra demand is for U.S. government liabilities not dollar-denominated assets. Equation (12), with a low risk premium applied to all U.S. government debt makes sense of these observations; a special demand for U.S. currency or dollar-denominated private deposits, a version of $M V(i, \cdot)=P Y$ 
does not.

Second, this mechanism for fluctuations in "aggregate demand" may apply more generally over time. Fluctuations in "aggregate demand" are somewhat mysterious, and fluctuations in demand for U. S. government debt do not easily line up with reasonable expectations of future surpluses. But accounting for the history of U. S. stock prices by news about expected dividends has been an even more catastrophic failure. The asset pricing literature has concluded that time-varying discount rates account for essentially all stock market price fluctuations. Perhaps we can similarly account for "aggregate demand" fluctuations by changes in the discount rate for government debt rather than (or as well as) changes in expectations of future surpluses. People fly to quality quite generally in recessions.

This view predicts that a variance decomposition of (12) will find that volatility in the value of government debt on the left will largely correspond to volatility in expected returns on the right rather than volatility in expected cashflows, just as Campbell and Shiller (1988), Cochrane (1992, 2008) and many others find for stocks, and even more analogously, as Gourinchas and Rey (2007) find for sovereign debt.

\subsection{Accommodation and stimulus}

We can understand many actions of the Treasury and Fed as attempts to accommodate the demand for government debt vs. private debt as well as by accommodating the demand for money relative to bonds.

\section{Open-market debt operations}

The Fed ran "open-market debt operations," exchanging private debt for government debt without changing the monetary base. As shown in Figure 6, between 2007 and September 2008, Treasuries and agency debt decline as a fraction of Fed assets (top graph), while the overall size of the Fed's balance sheet does not change much. From Jan 32007 to Sept. 3 2008 , for example, Fed holdings of Treasury securities declined from $\$ 779 \mathrm{~b}$ to $\$ 480 \mathrm{~b}$ while overall assets only increased from $\$ 911 \mathrm{~b}$ to $\$ 946 \mathrm{~b}$. The Fed provided the private sector about $\$ 300 \mathrm{~b}$ of Treasury debt in exchange for corresponding private debt.

The "Treasury" item in Federal Reserve liabilities, the bottom graph in Figure 6 represents a similar operation. The rapid rise here represents the Treasury Supplementary Financing Account. The Treasury sold additional debt and parked the proceeds with the Fed. Starting with $\$ 4 \mathrm{~b}$ on Sept. 92008 , the total Treasury account hit a peak of $\$ 621 \mathrm{~b}$ on Nov. 11 and was $\$ 502 \mathrm{~b}$ on Dec. 12 . The Fed turned around and lent this money or bought assets $^{3}$. On net, the government issued Treasury debt in exchange for private debt.

How might an "open-market debt operation"; a switch of private for government debt without changing $M$, "stimulate" the economy? Let $D_{t}$ denote private debt owned by the

\footnotetext{
${ }^{3}$ Lending and asset purchases are in many cases the same. Lending money creates private debt as an asset on the Fed's balance sheet.
} 
government. Our fiscal equation becomes

$$
\frac{M_{t}+B_{t}-D_{t}}{P_{t}}=E_{t} \int_{\tau=0}^{\infty} \frac{1}{R_{t, t+\tau}(M+B, \cdot)} s_{t+\tau} d \tau
$$

I write $R(M+B, \cdot)$ to capture the above idea that people are sometimes willing to hold government debt despite a low rate of return; the same "quality" premium discussed above. (Krishnamurthy and Vissing-Jorgenson (2008) give evidence for a Treasury-debt liquidity demand of this sort.)

Thus, by increasing the supply of Government debt, the discount rate $R$ rises (or the increased quantity offsets the deflationary effects of the flight to quality, captured in the . terms). Aggregate demand increases, even if government holdings of private debt $D_{t}$ offset greater government debt, so $B-D$ is unchanged, even if money $M$ is unchanged, and even if there is no surplus news so $s$ is unchanged.

\section{Guarantees}

The government also guaranteed large amounts of private debt, including Fannie and Freddie, guarantees of TARP bank credit, and guarantees of new securitized debt. The implicit guarantees of much larger amounts of debt - the widespread perception that no large financial institution will be allowed to fail - add to this list. To the extent that the private sector has a liquidity demand for debt with the government's credit rating, at the expense of debt which does not carry that guarantee, issuing such guarantees is the same thing as explicitly issuing Treasury debt in exchange for private debt.

\section{Interest on reserves}

The Fed has also started paying interest on reserves. Reserves that pay interest are government debt. By creating such reserves the Fed can rapidly expand the supply of shortterm, floating rate debt, without needing any cooperation from the Treasury or a rise in the Congressional debt limit. It also can execute massive open-market operations at the stroke of a pen. With a trillion dollars of excess reserves, changing the interest on reserves from 0 to the overnight rate is exactly the same thing as a trillion-dollar open-market operation.

\section{Balance sheet expansion}

In the second phase of accommodation, starting in September 2008, the Fed rapidly expanded its balance sheet. For the Fed, this means printing money (creating reserves) to buy assets rather than just exchanging private for Treasury assets. In conventional openmarket operations, we would have seen Treasury debt in Fed assets rise in tandem with the rise in reserves. Strikingly, the Fed took pains not to increase its holdings of Treasury debt, and to leave such debt in private hands. Fed holdings of Treasury debt stay low through the winter of 2009. The Fed funded the entire near-doubling of its liabilities by buying private assets instead. We can think of this as a nearly $\$ 1$ trillion conventional monetary expansion coupled with a $\$ 1$ trillion "open-market debt operation."

The government also increased the supply of government debt overall. Not only is $B+M-$ $D$ rearranged, it's much larger by the $\$ 1.5$ trillion fiscal deficit. This might represent fiscal 
stimulus, described next, but even if $s_{t+j}$ rises enough that there is no such fiscal stimulus, this action can be seen as helping to accommodate the large demand for government debt.

In sum, in this analysis, we can read the government's actions as a much-modified version of Friedman and Schwartz's advice for the great depression. In that event, the Fed failed to accommodate a demand for money at the expense of government debt. In this one, the government recognized and partially accommodated a massive demand for both money and government debt, at the expense of private debt.

\section{The Fed view}

This is not how the Fed thinks about its policy actions, at least as I interpret Fed statements. The first stage, trading private for government debt without increasing money, was, to the Fed, a way to support private credit markets without the inflationary effect that increasing $M$ might have had. The Fed wanted to stimulate in a noninflationary way, an idea beyond my simple analysis.

Similar thinking lies beyond the Fed's asset purchases. Starting in October 2008, the Fed started buying commercial paper, reaching $\$ 300$ b within a month. In early 2009, it started buying mortgage-backed securities, both directly and via agencies (the thin blue wedge in the top graph), and it started on an aggressive program of buying long-term treasuries, which you can see in the rise of the "treasury" component of Figure 6.

As I read Fed statements, the Fed was trying to attack interest rate spreads in these individual markets, not just to supply more government debt. The Fed sees somewhat "segmented" markets with liquidity premia higher than it thinks are appropriate, and it thinks that it can reduce the premiums in individual markets by buying securities in those markets. It hoped to do so by small purchases, or through the act of trading - by becoming the uninformed "noise trader" that liquefies finance models. In the event, it often ended up being almost the whole market for new issues, a position that makes affecting prices somewhat easier.

Whether the Fed was successful in affecting individual premiums in this way is an interesting question. Taylor (2009b) argues not, Ashcraft, Garleanu, and Pedersen (2010) argue yes. The opposite possibility is that the spreads on these assets represent credit risk and credit risk premiums; that the markets are not as segmented or liquidity-constrained as the Fed thinks, so that the Fed's purchases can do little to lower spreads for very long.

In turn, as I read Fed statements, these actions will "stimulate" by reducing interest rates faced by borrowers, also constrained to specific markets. Lower interest rates raise "demand," which in the first instance raises output and later leads to inflation by Phillips curve logic. This channel also requires frictions absent in my analysis.

Some of the issue is reminiscent of old debates in the analysis of monetary policy. When the Fed exchanges money for bonds, does it lower interest rates and raise aggregate demand by affecting the supply of money, or by affecting the supply of bonds? Conventional monetary economics takes the former view. The issue here is similar: when the Fed trades government debt for private debt, does this action affect rates and the economy by changing the supply of that particular form of private debt, or does it do so by changing the supply of government 
debt? Is the channel to overall demand via the interest rate on a particular form of private debt, or via the overall demand for government debt? Perhaps some of both; at a minimum my point is that the latter channel exists.

\section{$4 \quad$ Fiscal - monetary stimulus}

\section{Fiscal stimulus}

The U. S. government has also been engaged in a large "fiscal stimulus" designed to raise aggregate demand, with multi-trillion dollar deficits projected to last many years. From the view of most macroeconomic theory, the level of government spending and deficit finance matter, not the part labeled "stimulus," nor the nature of the spending, which dominate public debate. Will these deficits actually "stimulate" as promised?

The fiscal valuation equation

$$
\frac{M_{t}+B_{t}}{P_{t}}=E_{t} \int_{\tau=0}^{\infty} \frac{1}{R_{t, t+\tau}} s_{t+\tau} d \tau .
$$

offers a twist on the standard view of this issue: If additional debt $M+B$ corresponds to expectations of higher future taxes or lower spending, it has no "stimulative" effect. (Again, I leave the nominal/real split for later.) If, however, additional debt corresponds to expectations that future surpluses will not be raised, then indeed the the debt issue can raise aggregate demand.

This sounds like fairly standard "Ricardian equivalence" analysis. However, standard Ricardian equivalence presumes that the government issues real debt, always corresponding to higher expected future surpluses, so that some irrationality, market incompleteness or market failure is needed for any stimulative effect. Here, we realize that the government issues nominal debt. It can be perfectly rational for people to expect that the government does not plan to raise future surpluses, but that it plans instead to monetize debt when the debt comes due. And when they expect debt to be inflated away in the future, they try to dump it today.

I am abstracting here from distorting taxes, financial frictions, output composition effects, and the price-stickiness and multiple equilibria of New-Keynesian models, all of which potentially have important effects on the analysis of fiscal stimulus.. For example, Uhlig (2010) emphasizes distorting taxes; Christiano, Eichenbaum and Rebelo (2010) get large Ricardian (tax-financed are the same as deficit-financed) multipliers out of a New-Keynesian model with zero interest rates. My goal is only to analyze what $M V=P Y$ and (14) have to say about the issue before one adds other considerations, not to deny other channels or try to have a last word on an 80 year old debate.

\section{Will spending come too late?}

Many critics objected that fiscal stimulus won't stimulate in time, because the spending will come too late, after the recession is over. This reflects the standard analysis, enshrined in 
undergraduate textbooks since the 1970s, that fiscal policy, affects "demand" as it is spent. Equation (14) suggests the opposite conclusion. In order to get stimulus (inflation) now, future deficits $\left(s_{t+\tau}\right.$ for large $\left.\tau\right)$ are just as effective as current deficits, and possibly more so. What matters is to communicate effectively how that future deficits will be large, unlikely ever to be paid off with surpluses.

\section{Expectations.}

A fiscal stimulus/inflation is harder than it sounds. Government debt sales are deliberately set up to engender expectations that the debt will be paid off. Most of the time, governments do not sell debt to inflate; they sell debt to raise real resources that they can use for temporary expenditures like wars. If a debt sale comes with no change in expected future surpluses, it only raises interest rates and the price level. It raises no real revenue, and does not raise the real value of outstanding debt. Governments are usually very careful to communicate that this is not the case.

As an extreme contrast, consider a currency reform in which the government redeems the old currency and issues new currency with three zeros missing. This operation is exactly a debt rollover in which $B_{t}=B_{t-\Delta} / 1,000$, with no change in future surpluses, and no revenue. A currency reform is designed to communicate expectations that real surpluses will not change, precisely so that it will move the price level the next day and will not generate any revenue. The only difference between a currency reform and a debt sale is the expectations of future surpluses that each communicates.

Since the institution of a government debt sale is designed to convey the expectation that deficits will eventually be paid off, engendering the opposite expectations may be quite difficult. Everyone is used to meaningless long-term budget projections, especially in the U. S.

Currency reforms also have no output effects. Whatever price-stickiness, information asymmetry, or coordination problem gives rise to some temporary output rise from inflation, that mechanism is completely absent when the government undertakes a currency reform. Thus, the job for fiscal stimulus, in this analysis, is to sell debt while communicating that future surpluses will not rise - so that there will be some stimulus - but to do so in such a way that exploits whatever price stickiness or information asymmetry generates an output effect, which a currency will not do. Considering our knowledge about the precise mechanism of the Phillips curve, this is a challenging task.

\section{Quantitative easing; Helicopters; Joint Monetary/Fiscal policy; Japan.}

Fiscal stimulus came off the bookshelf in part because of the widespread view that monetary policy can do no more once interest rates hit zero.

When interest rates hit zero, the Fed can still pursue "quantitative easing." It can continue to buy Treasury or other debt, or lend directly, and thereby increase the money supply, even if these actions no longer affect short-term rates. People who think in terms of monetary aggregates rather than interest rates have advocated such easing. The Bank of England explicitly engaged in a quantitative easing program, and many commentators view the U. S. reserve expansion in this light. 
But in our framework, it's hard to see how quantitative easing can have any effect. The Fed can increase reserves $M$ and decrease $B$, but nobody cares if it does so. Agents are happy to trade perfect substitutes at will. Velocity $V$ will simply absorbs any further changes. The argument must rest on the idea that $V$ is fixed, but why should the relative demand for perfect substitutes be fixed? (With interest on reserves, the same logic applies even at nonzero interest rates, and one would expect the argument to hold as an approximation at small positive rates.)

What about a "helicopter drop?" Wouldn't this increase money $M$ and inflate? A helicopter drop is at heart a fiscal operation. To implement a drop in the U. S., the Treasury would borrow money, issuing more debt. It would spend the money as a government transfer. Then the Federal Reserve would buy the debt, so that the money supply increased. A real drop of real cash from real helicopters would be recorded as a transfer payment, a fiscal operation. Conversely, even a helicopter drop would not be "stimulative" if everyone knew that the money would be soaked up the next day in higher taxes, or by the Fed, i.e. by future taxes.

Thus, Milton Friedman's helicopters have nothing really to do with money. They are instead a brilliant device to dramatically communicate that this cash does not correspond to higher future fiscal surpluses; that this money will be left out in public hands as in a currency reform. To be effective, a monetary expansion at near zero rates must be accompanied by a non-Ricardian fiscal expansion as well. People must understand that the new debt or money does not just correspond to higher future surpluses.

The last time these issues came up was Japanese monetary and fiscal policy in the 1990s, to escape its long period of stagnation, low inflation and near-zero interest rates. Quantitative easing and huge fiscal deficits were all tried, and did not lead to inflation or much "stimulus." Why not? The answer must be that people were simply not convinced that the government would fail to pay off its debts. Critics of the Japanese government essentially point out their statements sounded pretty lukewarm about commitment to the inflationary project, perhaps wisely.

In sum, what matters, especially in an environment of near-zero rates, is the expectation of future deficits and surpluses. If you cannot persuade people that future surpluses will be absent, then exchanges of money for debt have no effect, and increases in money or debt have no effect. If you can convince people that these are lower than the real value of outstanding debt, then you can get inflation and, perhaps, some real stimulation along the way. But in that event, whether you drop money or treasury bills from the helicopter makes little difference.

\section{Identification}

This analysis implies that historical evaluation of fiscal multipliers suffers a (an additional) deep identification problem. What were expectations in previous events? If people expected eventual inflation, i.e. that the debt would not be paid off, we should see increased aggregate demand, and we would be able to measure the presence or absence of associated real stimulus. That experience would not inform us about the effects of a stimulus package that did come with a commitment not to inflate and therefore the expectation that future 
tax revenues would rise.

Expectations whether debt will be paid or inflated can vary considerably with the circumstances of the event. Wars are quite different from recession-fighting stimulus packages, and those are different from large promised social and retirement programs. Furthermore, stimulus packages come with different fiscal backgrounds. For example, Chile, with a large positive net asset position, is likely to face different expectations about long-run fiscal solvency of a large stimulus plan than are Italy or Greece, with larger outstanding debt.

\subsection{What are expectations?}

With this perspective in mind, what are expectations of future surpluses and deficits?

\section{Government announcements}

On one hand, we can take the Government's dramatic deficit projections surrounding the stimulus bill in January and February 2009 as loud announcements "you'd better spend the money now, because we're sure not raising taxes or cutting spending enough to soak it up." And long-term budget projections remain bleak. On March 202009 OMB director Peter Orszag was quoted to say "Over the medium to long term, the nation is on an unsustainable fiscal course." "Unsustainable" literally means that the right hand side of the fiscal equation is lower than the left. The normally staid Congressional Budget Office's (2009) Long Term Budget Update echoes the sentiment: "Over the long term ... the budget remains on an unsustainable path," complete with graphs of exponentially exploding debt.

On the other hand, the main problem in long-term budget projections are Social Security and medical entitlements. We've known that these programs are on an unsustainable course for years. This was not news during the winter of 2009. Markets had long had a reasonable expectation that sooner or later the government would get around to doing something about them. Furthermore, by spring 2009, the tone of government statements had changed completely from "stimulus" to concern over long-term budget deficits and a desire to lower them, not commit to them. OMB director Orszag's March 202009 "unsustainable" comment was followed quickly by "to be responsible, we must begin the process of fiscal reform now." It was delivered at a "Fiscal Responsibility Summit."

Most of the Administration's defense of fiscal stimulus (for example, Bernstein and Romer 2009) cites simple Keynesian flow multipliers from 1960s-vintage ISLM models, not the sort of fiscal-monetary inflation I have described as "stimulus." And by May, even these statements gave way to worries about fiscal sustainability that can be read as dramatically negative multipliers. For example, the Council of Economic Advisers' (2009) health policy analysis states that "slowing the growth rate of health care costs will prevent disastrous increases in the Federal budget deficit" and will raise the level of GDP by $8 \%$, permanently. By the winter of 2009-2010 the word "stimulus" disappeared from the Administration's lexicon. Arguments for "jobs" and mortgage-relief legislation made no mention of increasing the deficit, but were defended as microeconomic interventions that would help even if taxsupported. Chairman Bernanke's June 3 (2009b) testimony worries about long-term deficits, 
and thus whether the fiscal backing to contain rather than to produce inflation will be present.

Furthermore, Chairman Bernanke and the other Federal Reserve Governors are loudly saying the Fed can and will control inflation. Whether the Fed will be able to do so is another question, but at least we hear determination to fight and win any game of chicken with the Treasury. Secretary Geithner went out of his way to assure the Chinese that the dollar will not be inflated (Cha 2009).

In sum, government statements do not paint a clear picture. This may reflect an understandable indecision on the part of the government facing a Catch-22: In this analysis, the only way to "stimulate" is to commit forcefully and credibly to an unsustainable fiscal path, so that people will try to get rid of their government debt including money, and in so doing drive up demand for goods, services, and real assets. But such an action trades stimulus today for great financial and economic difficulty when deficits and inflation arrive.

\section{Measuring Ricardian expectations}

Ideally, none of this would matter. The bond market should let us measure private expectations. If the government sells additional debt and the private sector does not believe that debt will correspond to additional surpluses, then the real value of debt remains constant, the government raises no real revenue from the debt sale, and interest rates rise with inflation expectations. We know that interest rates and inflation have stayed low, and the government has raised trillions of dollars of revenue from its debt sales, and the real value of debt has risen dramatically. These facts suggest that for now, people believe that larger debt and near-term deficits are matched by expectations of longer-term surpluses. This observation also means that there hasn't been much fiscal-monetary stimulus as yet.

This analysis is clouded a bit by long-term debt. With outstanding long-term debt, the government can raise revenue from sales of long-term debt, diluting the outstanding longterm debt, as explained in Section 2.4. However, our government is raising revenue from short term debt sales, and the Fed actively purchased long-term debt, in an attempt to lower, not raise, interest rates.

More plausibly, we have to remember that economics is never easy because supply and demand both move. Long-term rates may reflect a good deal of flight-to-quality premium lower $R$ in the face of lower $s$, as argued above. We know that the expectations model of the term structure is a poor empirical fit. Thus, it's not immediately easy to read inflation expectations from the yield curve, nor to measure how much "stimulus" bond sales drove up nominal interest rates over what they would otherwise be. Other inflation indicators - the price of gold, for example - are rising steeply 


\section{$5 \quad$ Inflation or deflation?}

\subsection{Money and inflation}

Is a large inflation on the way? When the time comes to reverse course, will the Fed be willing to do so? More troubling, will the Fed be able to do so, or will we discover the fiscal limits to monetary policy? Will mounting fiscal deficits instead force the Fed to monetize even more debt? Will we in fact see a fiscal inflation without current monetization, but based on a flight from the dollar, a fear of future monetization, as (3) describes?

Opinions through 2009 were certainly mixed. Paul Krugman (2009) argues that "Deflation, not inflation, is the clear and present danger." Fed officials have given many comforting speeches on their "exit strategy." But Niall Ferguson (2009) Martin Feldstein (2009) and Anna Schwartz (Satow 2009) think inflation is on its way. Arthur Laffer (2009) thinks something like hyperinflation is on the way. These debates continue, with reports of a heated discussion within the Federal Reserve (Hilsenrath 2010).

$$
M V=P Y
$$

Some inflation hawks simply look at the vast amount of reserves and the smaller but substantial increase in M1 and currency, and infer that inflation must follow. Some of these observers, I think, are echoing a view that in $M_{t} V=P_{t} Y_{t}$, velocity is stable, but "long and variable lags" transmit money to inflation, so that past money must imply future inflation no matter what the Fed does subsequently. (Something like the "St. Louis equation" $\left.P_{t} Y_{t}=V \sum_{j=0}^{\infty} a_{j} M_{t-j}\right)$

In my view, this is simplistic: We now know that velocity does shift, especially at nearzero rates, and that today's money need not mean tomorrow's inflation if the Fed soaks that money up fast enough. What the Fed giveth, the Fed can taketh away.

For example, Laffer (2009) thinks M1 is the right aggregate; he worries that the huge expansion in reserves means more M1 expansion to come. Moreover, he worries that this process will then be difficult to reverse. If the Fed tries to soak up reserves, he thinks it will require a massive contraction in bank lending in order to reduce the relevant $M 1$, which will require a sharp recession that the Fed will not be willing to countenance. In the dove's view, we are still in a "liquidity trap" so the extra reserves aren't going anywhere in the first place.

I argued above that banks are just as happy to hold reserves as to hold government bonds. Their lending activity is disconnected from their reserve holdings. The fact that reserves now pay interest dramatically changes our interpretation of the data. Reserves that pay market interest are debt, not money. Finally, one can argue how difficult it will be for the Fed in fact to soak up aggregates even if the latter do expand. With ample excess reserves, and much interest-bearing bank financing, there is no necessary connection between the amount of bank lending or overall credit and the stock of any monetary aggregate. A cashless economy will still have lots of loans. 


\section{The Fed's balance sheet}

Feldstein (2009) points out that the Fed no longer has much Treasury debt, as you can see in Figure 6. If it wants to soak up reserves, it may be very hard to sell all the illiquid, long-dated and risky private securities that the Fed has accumulated, and impossible to sell direct loans. Feldstein writes "..the commercial banks may not want to exchange their reserves for the mountain of private debt that the Fed is holding and the Fed lacks enough Treasury bonds with which to conduct ordinary open market operations.."

I do not think this is much of a constraint-or rather it's an internal political constraint not a fundamental economic constraint. There is nothing that stops the Fed and Treasury together from simply issuing new Treasury debt to soak up the trillion dollars or so of reserves, even if the Fed has nothing left on its balance sheet. The Treasury can issue new debt, and simply deposit the proceeds with the Fed, as it already did; the Fed need only abstain from lending them out again. Furthermore, by raising the interest rate on reserves, the Fed can essentially create debt and execute an open-market operation with the stroke of a pen.

\section{Will and ideas}

Many inflation hawks really have in mind political rather than economic constraints, which my analysis has little to say about. They question whether the Fed will have the will or political ability to start soaking up reserves or raising short-term interest rates quickly enough. The "credit crunch" and "financial crisis" were over by mid 2009 - short-term debt spreads returned if not to normal, at least to functioning levels. The "flight to quality" is fading as well, and long-term rates rebounded. Yet we will still be in a serious recession for some time. Commercial real estate, state debt, and some pension funds are still in trouble. Mortgage foreclosures are continuing. Unemployment will be high for some time. Many financial institutions will still be on the edge, and many of them make a lot of money by borrowing low and short and lending long. To the extent that the Fed's asset purchases lowered specific rates in commercial paper, mortgage and other markets, now there are constituencies who can plead for specific support.

Constraints imposed by ideas and information are a more subtle route to inflation. This path constitutes the conventional analysis of inflation in the 1970s (For example, see Sargent 1999 and Samuelson 2008). Will the Fed's "potential GDP" estimates, as in the 1970s, suggest large and illusory "gaps" remaining to be filled? Will the Fed interpret house and stock prices below their peaks as "asset price deflation" that counteracts goods and services inflation? Will the Fed continue to believe that expectations are "anchored" until they no longer are, when it is too late? The Fed seems focused on "managing expectations" by announcements rather than direct open market operations in order to control inflation. Will it continue too long to trust in that ability?

\section{Fiscal constraints on a monetary exit}

I conclude that no substantial monetary or economic problems stop the government from soaking up whatever assets constitute the $M$ in $M V=P Y$ and removing monetary stimulus, if it wants to do so and if it can suffer the higher short-term interest rates that this action 
may provoke. The remaining question is fiscal backing - whether the government will be able to undo monetary expansion.

For the next several years, the Treasury will still be selling trillions of additional debt to finance deficits. If investors and the Treasury are also trying to sell, can the Fed sell additional trillions as well? For example, Laffer (2009) writes "If the Fed were to reduce the monetary base by $\$ 1$ trillion, it would need to sell a net $\$ 1$ trillion in bonds. This would put the Fed in direct competition with Treasury's planned issuance of about $\$ 2$ trillion worth of bonds over the coming 12 months. Failed auctions would become the norm and bond prices would tumble, reflecting a massive oversupply of government bonds." By (3), or better (13), this is false. Prospective investors in new government debt were already holding currency or reserves, which are just a different maturity of government debt. It takes almost no additional fiscal resources to unwind a reserve or currency expansion. ("Almost" because of the potentially higher interest cost of non-monetary debt, but seigniorage is tiny; $1 \%$ of $\$ 1$ trillion dollars is $\$ 10$ billion.) Additional resources, new debt issues matched by higher future surpluses, are important to a government that needs foreign reserves, gold reserves, etc. in order to unwind a monetary expansion, but not to a government that wants to unwind an expansion of domestic reserves.

I conclude that the U. S. has both the ability and fiscal capacity to rapidly unwind its monetary expansion, should the government choose to do so.

\subsection{Fiscal inflation}

A fiscal inflation, the consequence of current and future deficits, are therefore, in this analysis, a greater inflation danger than monetary policy and the existence of an "exit strategy."

Reading the commentators, I think there is in fact widespread agreement on this danger, just diverging opinion as to its probability. Even Krugman (2009) admits "others claim that budget deficits will eventually force the U.S. government to inflate away its debt..." The possibility is that the U. S. will " drive up prices so that the real value of the debt is reduced. Such things have happened in the past. For example, France ultimately inflated away much of the debt it incurred while fighting World War I." The danger is well described by (3); he just doesn't think it will happen.

How exactly does this work, what are the warning signs? Here again, I think looking at (3) clarifies some issues and points out some common traps.

\section{Debt/GDP ratios and future deficits}

Krugman and other inflation doves assure us that the U. S. debt/GDP ratio is below that of many other countries, and our own past experience. The CBO analysis in Elmendorf (2009), for example, shows our current debt/GDP at 40\%, and projected to rise to $60 \%$ during the current recession. This is small compared to the $110 \%$ debt/GDP ratio at the end of WWII, and the ratios over 100\% that several European countries and Japan now experience.

The long-term U. S. budget outlook is much more bleak. It is unusual that even the 
CBO's 10 year forecast does not show steady deficit reduction. However, the long-term "unsustainable" trends are driven by social security and health expenditures, not recessionfighting stimulus, and even under the CBO's more plausible "alternative fiscal scenario" we only reach $100 \%$ of GDP in about 2022 and $200 \%$ of GDP in 2035. What's to worry about?

Most of all, the fiscal equation (3) does not point to a "sustainable" debt/GDP ratio - say $100 \%$ - and "everything will be fine until you cross this point." Equation (3) says that you get inflation now as soon as people think that future debt/GDP ratios will grow uncontrollably, i.e. the left hand side is greater than the right. If anyone believed the CBO's long-term forecasts, inflation would have already happened. People expect that eventually the government will do something about Social Security, Medicare and entitlements. Other countries have experienced exchange rate collapses - meaning, their governments were unable to pledge enough real resources to borrow foreign exchange reserves - with much lower than $100 \%$ current debt/GDP ratios, when markets saw unsustainable prospective deficits. Burnside, Eichenbaum, and Rebelo's (2001) analysis of the 1997 Asian currency crashes are a good example, and the international literature finds that current debt/GPD ratios are generally not a good forecast of currency crashes or their absence. Conversely, even very large debt is possible if people understand there is a plan to pay it off. The U.S. could borrow $120 \%$ of GDP at the end of WWII because everyone understood war expenditures were temporary, we won the war, and that huge deficits would end once that temporary exigency passed. Finally, the fact that other countries have greater debt could only mean that they we will all experience inflation.

GDP is not even a very good divisor. U. S. Federal tax revenues are about $15 \%$ of GDP, so a $60 \%$ debt/GDP ratio is a $400 \%$ debt/revenue ratio. Comparing debt to GDP only makes sense across countries with comparable tax systems. To harvest European taxes, the U.S. would have to institute a national VAT, which will hardly be painless. To put the observation another way, we can ask what changes in tax rates under the current U.S. tax system would eliminate forecasted deficits. Congressional Budget Office Director Peter Orzag (2008) did this, concluding that the lowest bracket would have to rise from 10 percent to 25 percent; the 25-percent bracket would have rise to 63 percent; and the top rate would have to rise from 35 percent to 88 percent, before considering any effort or evasion effects. Including such effects, the needed tax revenues are beyond the top of the Laffer curve: "Such tax rates would significantly reduce economic activity and would create serious problems with tax avoidance and tax evasion. Revenues would probably fall significantly short of the amount needed to finance the growth of spending; therefore, tax rates at such levels would not be feasible."

Bond rating agencies use other ratios as well. Graham (2010) reports that Moody's may downgrade US government debt from AAA status as soon as 2013, based on CBO projections that interest will climb to $20 \%$ of revenue. Interest expense/revenue is not a sure sign of fiscal trouble or security as well, but can point in a quite different direction from current debt/GDP.

\section{Crowding out}

Much discussion of the dangers of deficits focuses on the flow of spending, and its potential 
effect on interest rates through a "crowding out" mechanism; higher deficits compete for savings. The fact that international debt markets are huge and there is little historical association between deficits and interest rates has always argued against this mechanism.

In any case, nothing like this mechanism is mirrored in the fiscal equation (3). One can have high inflation with no current deficits at all, if expected future deficits are high. The size of U.S. debt relative to international markets is irrelevant; what matters is the size of U. S. debt relative to the U. S. ability to run surpluses. Long-term nominal rates do not rise because flow deficits crowd out private investment. They simply reflect expected future inflation and a risk premium for government debt.

\section{Seigniorage, monetization, "chicken."}

Most writing about the dangers of deficits focuses on the idea that the Fed will have to monetize deficits, this action will raise the money stock, and only then will inflation break out. Equation (3) emphasizes that we can have inflation now when people expect future monetization. We do not have to wait for seigniorage. There doesn't even have to be any seigniorage.

Now, $M V(i, \cdot)=P Y$ reminds us that even a fiscal inflation has to be accommodated by monetary authorities. If $P$ in the fiscal equation rises, but the Fed adamantly refuses to raise $M$, we have an "uncoordinated policy." One side must give way in a "game of chicken." The Fed gives way automatically when it follows an interest rate target or otherwise passively adjusts money in response to liquidity needs, as it has been explicitly and aggressively doing for the past year. Whether it can prevail in a serious fiscal exigency is an interesting and open question. Would the Fed refuse to monetize if the U.S. ran in to very high interest rates when trying to roll over debt? Or would it quickly give in, as the ECB did in purchasing junk-rated Greek bonds?

\section{The picture}

In sum, the fiscal valuation equation

$$
\frac{M_{t}+B_{t}-D_{t}}{P_{t}}=E_{t} \int_{\tau=0}^{\infty} \frac{1}{R_{t, t+\tau}} s_{t+\tau} d \tau .
$$

and experience of past fiscally-induced collapses paints a far different picture of a fiscal inflation than in most commentator's scenarios. This equation looks (and is) a lot like the valuation equation for a stock. Hence, a fiscal inflation may well look like a stock market collapse. The tipping point, where investors change expectations of long-term future surpluses $s$, valuations of government-held assets $D$, or require larger real risk premiums $R$ to hold them, can come quickly and unpredictably, without necessarily large current debt/GDP, large current deficits, large current monetization; without strong "demand" and small "gaps." It can come as a surprise to a Federal Reserve and to economists unused to thinking about fiscal limits to monetary policy. Since the long present value results from rolling over short-term debt, difficulties in that roll over may be one of the first signs.

Where is the fiscal limit? I don't know. But there is a fiscal limit, and wherever it is, we are a few trillion dollars closer to it than we were last year, and we will be another few 
trillion dollars closer next year. The next two considerations suggest it is closer than we think.

\subsection{Credit guarantees, nominal commitments, and the fiscal limit}

If official debt-to-GDP ratios are "only" headed to $100 \%$ or so, there is still a lot of off-thebooks nominal debt. Define-benefit pensions, unused nominal depreciation allowances, and even nominally-sticky government salaries are all forms of nominal debt.

The U.S. government has made very large credit guarantees. The government has explicitly guaranteed Fannie and Freddie debt and underlying mortgages, the TARP banks debt, student loans, and many others. Implicit guarantees are potentially as large or larger. Fed Chairman Ben Bernanke ${ }^{4}$ has pretty much guaranteed that no large financial firm will fail. Immense bailouts loom of state and local governments, defined-benefit pension plans, and foreign sovereign debt either directly or via the IMF. For example, Rauh and Novy-Marx (2009) estimate that state pension obligations are underfunded by $\$ 3.23$ trillion, dwarfing the states' publicly traded debt of $\$ 0.94$ trillion. The Federal Government is unlikely to let states or their pensions default.

Credit guarantees have two effects. First, and most obviously, having to make good on these guarantees on top of large budget deficits can be the piece of bad news that kicks expectations over the fiscal limit. Second, nominal credit guarantees and other nominal or poorly indexed commitments, mean that government finances are much better if there is inflation. Higher nominal real estate prices will surely make the government's mortgage and banking guarantees much easier to fulfill. We can treat these guarantees as additional nominal debt, or we can count the flows, and recognize that surpluses are not independent of the price level. In this treatment, our equation is really

$$
\frac{M_{t}+B_{t}}{P_{t}}=E_{t} \int_{\tau=0}^{\infty} \frac{\Lambda_{t+\tau}}{\Lambda_{t}} s_{t+\tau}\left(P_{t+\tau}\right) d \tau
$$

with $s^{\prime}(P)>0$. For example, Burnside, Eichenbaum and Rebelo (2006) find that the Korean devaluation helped government finances largely by lowering the real value of nominal wages paid to government workers, rather than devaluing domestically-denominated nominal debt - the mechanism was $s(P)$ not $B / P$. More deeply, guarantees are options with a nonlinear payoff, making deflation much worse than inflation is helpful for government finances.

This consideration means that a smaller inflation can solve a larger budget problem, since a rise in $P$ makes the right side larger as well as the left side smaller. Put another way, the U.S. problem, large prospective deficits with a relatively small stock of outstanding debt, would otherwise put us in a real fiscal pickle, since we can't devalue debt we haven't issued yet. Even an infinite price level - a default of all outstanding US debt, cutting future interest payments to zero - is not enough to pay for the CBO's projections of Social Security and

\footnotetext{
${ }^{4}$ See Bernanke (2009a), and in particular, "..government assistance to avoid the failures of major financial institutions has been necessary to avoid a further serious destabilization of the financial system, and our commitment to avoiding such a failure remains firm."
} 
Medicare deficits. On the other hand, the fact that real surpluses increase with inflation makes it much more likely that the government will choose inflation rather than explicit spending cuts. Again, one should not think of surpluses as exogenous in this fiscal analysis. Really we should think of the Government's decision to inflate, trading off distorting taxes, useful or politically popular spending, and the distortions caused by inflation, and the ability to place blame elsewhere in making this decision.

\subsection{The dynamic Laffer curve and the fiscal limit}

The point at which higher taxation simply cannot raise any more revenue - the top of the "Laffer curve" - is one fiscal limit ${ }^{5}$. Since present values matter, small effects of tax rates on growth can put us at the fiscal limit much sooner than static analysis suggests. Thus, a high marginal tax and interventionist policy which stunts growth can be particularly dangerous for setting off a fiscal inflation.

We are used to thinking of the static Laffer curve, in which tax revenue $T_{t}$ is generated by a tax rate $\tau_{t}$ from income $Y_{t}$ as

$$
T_{t}\left(\tau_{t}\right)=\tau_{t} Y_{t} .
$$

The marginal revenue generated from an increase in taxes is

$$
\frac{\partial \log T_{t}}{\partial \log \tau_{t}}=1+\frac{\partial \log Y_{t}}{\partial \log \tau_{t}}
$$

The second term is negative - higher taxes lower output (and, more so, reported income), so the elasticity of tax revenues with respect to tax rates is less than one. The top of the Laffer curve is where the elasticity is equal to zero, so higher tax rates raise no revenue.

Many economists think the U.S. is comfortably below that point. For example, a rise in the tax rate from $\tau=0.30$ to $\tau=0.35$ is a $15 \%(\log (0.35 / 0.30)=0.15)$ increase, so it would have to result in a $15 \%$ decline in taxable output before it generates no additional revenue. (Yes, this calculation is too simple. The point is to contrast this calculation with the dynamic calculation below, not to assess realistically the U.S. tax system. Trabandt and Uhlig (2009) offer a detailed Laffer calculation with fixed productivity growth and no migration, yielding the result that the US is substantially below the Laffer limit.) More people voiced concern that the UK's recent move to a $50 \%$ marginal rate plus VAT put it above the top, especially since high-wealth people can leave. When tax rates are already high, the same percentage point tax rate rise is a smaller percentage (log) rise, so smaller output effects of each percentage point tax rise are necessary to offset the tax rate increase.

The present value of future tax revenues is what matters for the fiscal valuation equation, however. For a simple calculation, suppose growth of taxable income is steady at rate $g$ and the interest rate is a constant $r$. Then, the present value of future tax revenues is

$$
P V_{t}=\int_{s=0}^{\infty} \frac{1}{e^{r s}} \tau Y_{s} e^{g s} d s=\frac{\tau Y_{t}}{r-g}
$$

\footnotetext{
${ }^{5}$ See Piergallini and Rodano (2009) for a model of the Laffer limit in fiscal theory.
} 
Taking the same derivative,

$$
\frac{\partial \log P V}{\partial \log \tau}=1+\frac{\partial \log Y}{\partial \log \tau}+\frac{1}{r-g} \frac{\partial g}{\partial \log \tau}
$$

We see there is an additional term, which is also negative.

Since $r-g$ is a small number, small growth effects can have a big impact on the fiscal limit. For example, if $r-g=0.02$, then $\partial g / \partial \log \tau=-0.02$ puts us at the fiscal limit immediately. Thus, if a rise in $\tau$ from $30 \%$ to $35 \%$ only implies a $0.02 \times 0.15=0.3 \%$ reduction in long term growth, then we're at the fiscal limit already, disregarding the flow effect $\partial \log Y / \partial \log \tau$ entirely.

I do not digress here to the economics by which marginal tax rates lower the level or growth rate of output. The disincentive effects of working, saving or investing, and the incentives for tax evasion, are widely discussed. Migration of high-wealth people and businesses is perhaps even more important, especially to small countries: Even if growth per capita is not affected by distorting taxes, fewer capitas mean less tax revenue. Growth theory points to accumulation of knowledge as the main driver of long run per-capita growth rates, but I don't want to stop here to model how distorting taxes interfere with that process, nor tie the calculation to one particular such model.

\section{Phillips curves-Will inflation "stimulate?"}

The point of stimulus is not to inflate, of course, but to boost output in the short run. Many economists argue that a little inflation isn't such a bad thing in the current circumstance, as they argued for deliberate inflation in Japan in the 1990s. For example, Greg Mankiw and Ken Rogoff are quoted in Miller (2009) as being in favor of inflation, on Phillips curve grounds to raise output as well as to bail out borrowers at the expense of nominal debt holders.

I have not described a particular mechanism for output effects, in part because both the theory and experience of Phillips curves under fiscal inflations is unexplored territory. But it is worth remembering that not all inflations come with output booms either in theory or in practical experience. There is no guarantee that inflation will "stimulate" the real economy. Inflation with real stagnation is a possibility too.

\section{Experience}

We have many precedents against a rigid Phillips curve in traditional monetary analyses and historical experience. Of course we all understand that currency reforms (exchanging old currency for new, with fewer zeros, or moving to the Euro) change the price level with no output effects at all.

The 1970s had inflation with recession or stagnation. This experience is captured in two ideas: "aggregate supply" shifted adversely, and inflation expectations rose, or its "anchoring" disappeared, shifting the Phillips curve up and to the right. As a visual reminder of 
how weak even the Phillips curve correlation is, Figures 8 and 9 present a history of U.S. inflation and unemployment, broken up into two subperiods for visual clarity.

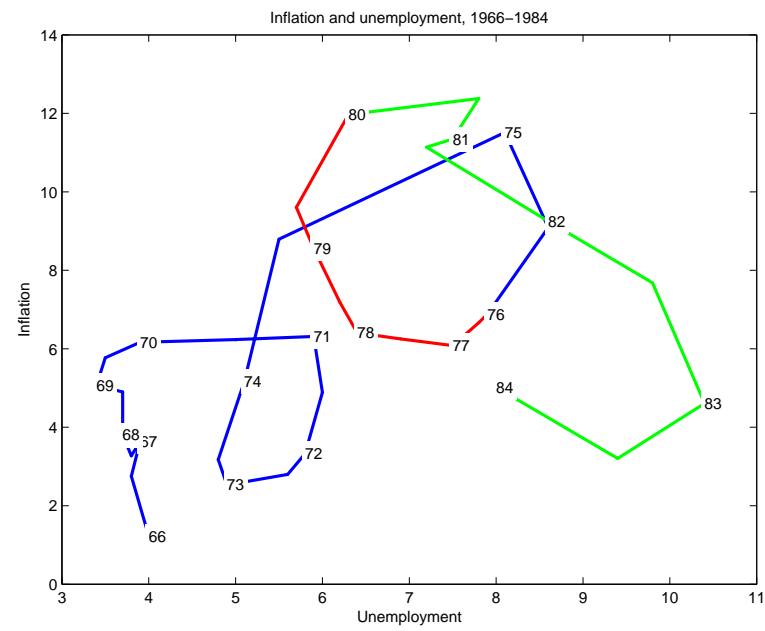

Figure 8: CPI inflation and unemployment, 1966-1984

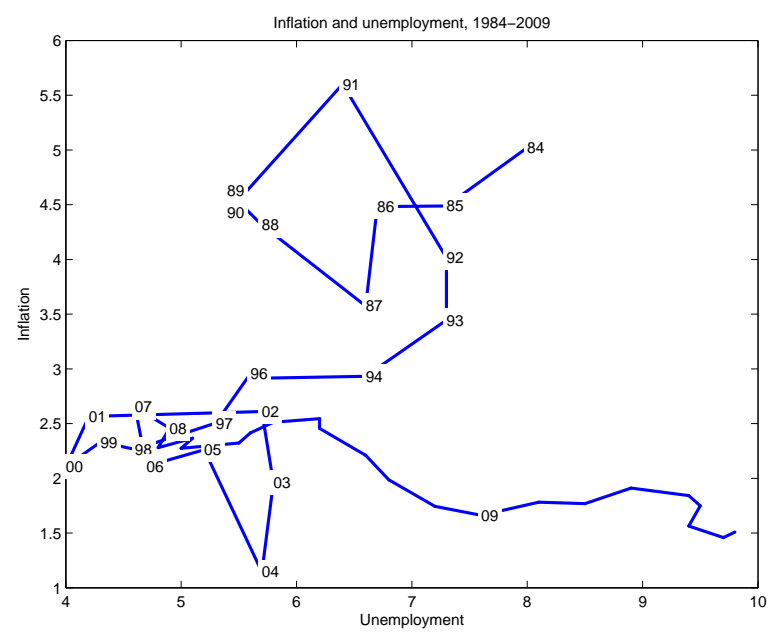

Figure 9: CPI inflation and unemployment, 1984-2009

The larger history of fiscal inflations and currency collapses does not inspire hope that a fiscal inflation always results in prosperity. The hyperinflations that follow wars (Sargent 1992), Latin American fiscal collapses, currency crashes, or the recent hyperinflation in Zimbabwe were associated with sharp declines in economic conditions, not the spectacular booms that a simple Phillips curve might predict.

This wider experience is worth considering. Most economists view the postwar U. S. experience as one that comes from a regime in which the fiscal constraint was not important. If we run in to fiscal constraints, however, our future will not be drawn from this same 
experience. If that happens, we may find that a comfortable idea of booms associated with inflations will vanish once again.

Fiscal anchor. Fiscal stagflation? Explicit models.

In any monetary-fiscal analysis, the fiscal equation (3) is a central part of the "anchoring" of inflation expectations necessary for successful monetary policy. Monetary policy needs fiscal backing. This insight suggests that a fiscal inflation is likely to correspond to a "Phillips curve shift," which would lead to stagflation, not inflation with a boom. A fiscal inflation may also correspond to poor output through an "aggregate supply shift;" Governments resort to distorting taxes before they "default" through inflation.

To give one quantitative assessment of a fiscal inflation's output effects, I use a textbook New-Keynesian model, for example see Woodford (2003),

$$
\begin{aligned}
y_{t} & =E_{t} y_{t+1}-\sigma r_{t} \\
\pi_{t} & =\beta E_{t} \pi_{t+1}+\gamma y_{t} \\
i_{t} & =r_{t}+E_{t} \pi_{t+1},
\end{aligned}
$$

where each symbol represents deviations from a steady state. ( $y$ is output, $r$ is the real rate, $\pi$ is inflation, and $i$ is the nominal rate. The second equation is the New-Keynesian Phillips curve.) Given the response of inflation to a shock, and in particular a choice of one of the inflation scenarios in Figure 3, we can simply compute the corresponding paths for output, and real and nominal interest rate responses to the shock, $\left\{y_{t}\right\},\left\{r_{t}\right\}$ and $\left\{i_{t}\right\}$, from (16), (15) and (17) in turn. We can regard the interest rate path as a calculation of what interest rate policy was required to lead to the inflation outcome ${ }^{6}$.

Figure 10 gives the results. In response to a time-zero surplus present value shock, I specify a path for inflation similar to that in the delayed-inflation scenario of Figure 3, but with rounded corners to avoid otherwise large movements in output and real and nominal interest rates. (The latter are essentially first and second derivatives of inflation in (15)-(17).)

The major news of Figure 10 is that output declines through the entire inflation episode. This is stagflation, not a boom; a march of the Phillips curve up and to the right as in the 1970s. The reason is transparent: The inflation is all expected; expected inflation rises before actual inflation. The forward-looking Phillips curve $\pi_{t}=\beta E_{t} \pi_{t+1}+\gamma y_{t}$ implies lower output; $E_{t} \pi_{t+1}$ is a "Phillips curve shift."

Real interest rates decline in the stagflation, and rise again when output recovers. The nominal rate is a simple sum of expected inflation and the real rate. (Again, the solution is the same if we regard the nominal rate as the policy lever, debt sales as the instrument, and inflation as the result.) Since the nominal rate falls with output growth and then rises in the recovery, the overall rise in nominal rate is greater than the rise in inflation. An observer might well conclude that the Fed is properly following a "Taylor rule" with interest rates

\footnotetext{
${ }^{6}$ With "active" fiscal policy of the form (3) we do not have to specify policy as a function of endogenous variables in the form of a Taylor rule; the equilibrium is the same given the eventual value of the interest rate whether that interest rate varies with off-equilibrium values of endogenous variables or not. An "active" fiscal policy solves the global indeterminacy problems of New Keynesian models, see Cochrane (2007).
} 


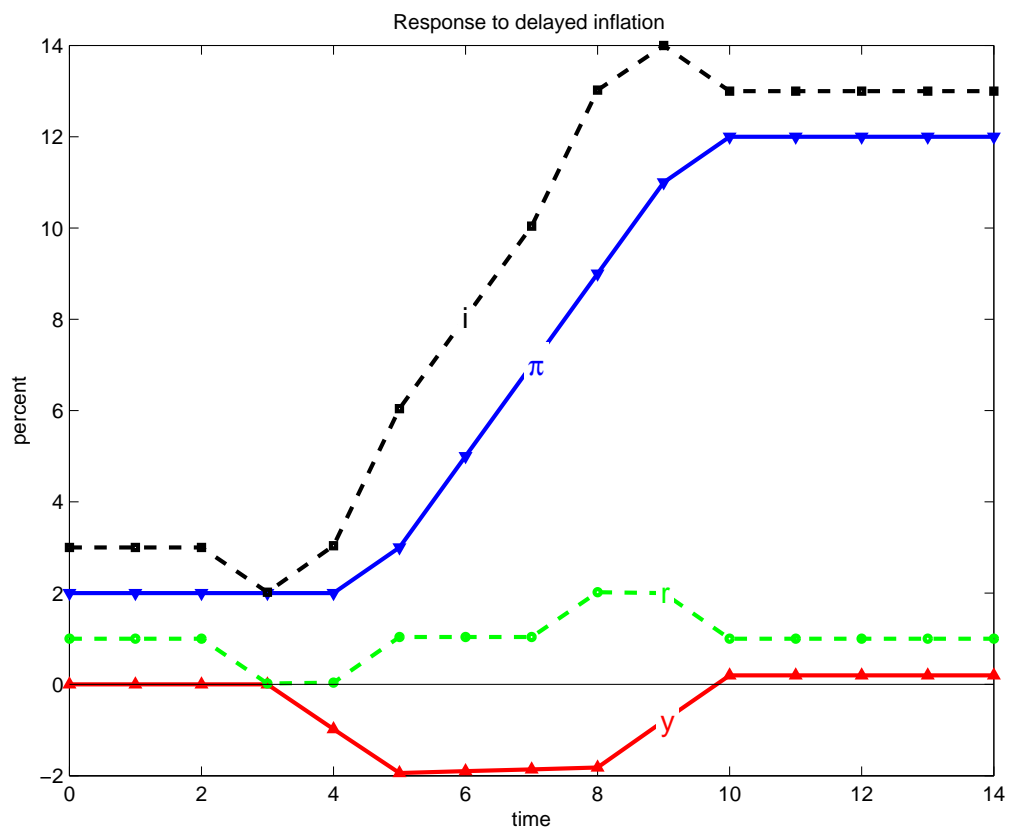

Figure 10: Output and real and nominal rates in a "delayed inflation" scenario. I assume the path of inflation. Given that path, I calcuate output $y$, the real rate $r$ and the nominal rate $i$ respectively, using $\pi_{t}=\beta E_{t} \pi_{t+1}+\gamma y_{t} ; y_{t}=E_{t} y_{t+1}-\sigma r_{t} ; i_{t}=r_{t}+E_{t} \pi_{t+1}$ respectively. I use $\beta=0.98, \gamma=1, \sigma=1$. These expressions represent deviations from a steady state. I plot $r, \pi$ and $i$ around steady-state values $1 \%, 2 \%$, and $3 \%$ respectively for clarity.

declining in the recession, rising faster than inflation, and rising with rising output growth. Yet a mysterious inflation coming from "loss of anchoring" bedeviled its efforts. In a sense, that is exactly what happened.

Of course, there are many different versions of the Phillips curve, with slightly different timing. But expected inflation is a "shift" in almost all of them, so this scenario, of a widely anticipated inflation, is unlikely to give much of an output boom in any model.

In this scenario, the government delayed and smoothed inflation from a surplus shock at time zero, accepting a larger eventual increase in the price level. This analysis points to an apparent further cost of delay. A time-zero price level jump is unexpected, and could be followed by a return to zero inflation; that path would lead to more output. However, such a policy would also lead to an equal number of negative innovations, and more output instability in general.

One may rightly object that this simple marriage of a fiscal equation to a three equation New-Keynesian model needs a lot more theoretical elaboration and empirical evaluation before predicting anything. In particular, it's hard with this simple Phillips curve to account for the severity of the output drop in the recession. Yes, the recession is unexpected while this scenario studies an expected inflation, but the 2008 decline in inflation is modest. A view that people expected a quick return of inflation is unlikely. One needs either a different and more realistic Phillips curve, as is common in the empirical literature, or to add shocks. 
More deeply, we need to understand better the operation of this "active fiscal, passive money" regime (using Leeper's 1991 terminology) of models with explicit price-stickiness.

Finally, it is not clear that all fiscal inflations will have the same output effects. In the fiscal context,

$$
\frac{M_{t}+B_{t}}{P_{t}}=E_{t} \int_{\tau=0}^{\infty} \frac{1}{R_{t, t+\tau}} s_{t+\tau} d \tau
$$

inflation can follow from issuing more money $M_{t}$ or debt $B_{t}$ (or long-term debt $B_{t}^{(j)}$ ) without changes in surpluses; from shocks to prospective deficits $s_{t+j}$, causing a flight from debt, or from a rise in the risk premium $R_{t, t+\tau}$. It's not at all obvious that each of these changes is accompanied by a boom or by the same boom. We have some sense that unexpectedly printing up a lot of money - a fiscal helicopter drop - might give a short-term output boost, especially if it were done as a surprise. However, the experience of fiscal inflations caused by current and prospective deficits - currency collapses - is not comforting.

\section{Standard views}

Here I part company with most of the inflation/deflation commentators and the Federal Reserve. All of them link inflation tightly to increased "demand" and hence tighter markets.

In a revealing statement, Chairman Bernanke (2009b) said to Congress,

Even after a recovery gets under way, the rate of growth of real economic activity is likely to remain below its longer-run potential for a while, implying that the current slack in resource utilization will increase further. ...In this environment, we anticipate that inflation will remain low. The slack in resource utilization remains sizable, and, notwithstanding recent increases in the prices of oil and other commodities, cost pressures generally remain subdued. As a consequence, inflation is likely to move down some over the next year relative to its pace in 2008. That said, improving economic conditions and stable inflation expectations should limit further declines in inflation.

Throughout 2009 and 2010 the FOMC has been issuing nearly identical statements. This one is from March 16 2010:

"With substantial resource slack continuing to restrain cost pressures and longer-term inflation expectations stable, inflation is likely to be subdued for some time.

The Committee ... continues to anticipate that economic conditions, including low rates of resource utilization, subdued inflation trends, and stable inflation expectations, are likely to warrant exceptionally low levels of the federal funds rate for an extended period."

So, inflation is caused by "tightness" (the opposite of "slack") in the economy. This is not just $a$ cause and forecasting variable, it is the cause, because given "slack" we apparently 
don't have to worry about inflation from other sources, notwithstanding the weak correlations of Figures 8 and 9

These statements do mention "stable inflation expectations." How does the Fed know expectations are "stable" and won't come unglued once people look at deficit numbers? As I read Fed statements, almost all confidence in "stable" or "anchored" expectations comes from the fact that we have experienced a long period of low inflation (adaptive expectations). To a lesser extent, the Fed relies on survey data and interest rate data. For example, Chairman Bernanke (2010b) asserted again in his February 242010 testimony that "according to most measures, longer-term inflation expectations have remained relatively stable." The accompanying semiannual report on monetary policy (Federal Reserve 2010) mentions inflation expectations three times. The first asserts that "inflation expectations have been relatively stable" and points to a graph (figure 2) of actual inflation. The second (under "prices") summarizes median survey data, excusing a jump in short-term expectations by energy prices and pointing to more stable long-term expectations. The third inferred expectations from Treasury vs. TIP yields, again arguing that "short-term" expectations might have risen but "long-term" expectations had not changed much. These are the only mention of expectations or documentation of the FOMC and Chairman's assertions in the document. Occasionally, sophisticated Fed statements allude to the New-Keynesian idea that expectations are anchored by a belief that the Fed will respond quickly to inflation, though not why people should have such a belief. The volume of popular press coverage of deficits and inflation - clearly about expected future inflation - and even the ads for gold on cable TV suggest at least a more widespread concern about inflation than has been present for some time.

In particular, Fed statements make no mention of fiscal constraints on monetary policy, the possibility that fiscal inflation can erupt and there is little the Fed can do about it, or that uncontrolled deficits may quickly induce higher inflation expectations. Two exceptions suggest the rule: One of the few recent Fed statements on our fiscal position is this, from Chairman Bernanke's (2009c) July 212009 testimony:

..maintaining the confidence of the public and financial markets requires that policymakers begin planning now for the restoration of fiscal balance. Prompt attention to questions of fiscal sustainability is particularly critical because of the coming budgetary and economic challenges associated with the retirement of the baby-boom generation and continued increases in the costs of Medicare and Medicaid. Addressing the country's fiscal problems will require difficult choices, but postponing those choices will only make them more difficult. Moreover, agreeing on a sustainable long-run fiscal path now could yield considerable near-term economic benefits in the form of lower long-term interest rates and increased consumer and business confidence. Unless we demonstrate a strong commitment to fiscal sustainability, we risk having neither financial stability nor durable economic growth.

Though warning against deficits, the main danger Chairman Bernanke sees from an unsustainable debt path is higher long-term interest rates, presumably from a flow crowding 
out argument, and less "confidence."

Addressing the National Commission on Fiscal Responsibility and Reform on April 27, 2010, (Bernanke 2010c) he went further,

Increasing levels of government debt relative to the size of the economy can lead to higher interest rates, which inhibit capital formation and productivity growth-and might even put the current economic recovery at risk. To the extent that higher debt increases our reliance on foreign borrowing, an ever-larger share of our future income would be devoted to interest payments on federal debt held abroad. Moreover, other things being equal, increased federal debt implies higher taxes in the future to cover the associated interest costs-higher taxes that may create disincentives to work, save, hire, and invest. High levels of debt also decrease the ability of policymakers to respond to future economic and financial shocks; indeed, a loss of investor confidence in the ability of a government to achieve fiscal sustainability can itself be a source of significant economic and financial instability, as we have seen in a number of countries in recent decades.

These are all important points, but only the last sentence begins to give a glimmer of the fiscal equation's warning - that when investors question fiscal sustainability, inflation can break out despite ample "slack" and there is nothing the Fed can do about it.

Other commentators on both sides evoke similar views. Krugman (2009) writes "[in ordinary times]...banks, flush with reserves, would increase loans, which would drive up demand, which would push up prices." Laffer (2009) describes the same mechanism. Feldstein (2009) describes a more general "demand" based mechanism: "The key fact is that inflation rises when demand exceeds supply. A fiscal deficit raises demand when the government increases its purchase of goods and services or, by lowering taxes, induces households to increase their spending..." Again, he's worried about crowding out, not a flight from the debt and stagflation.

All of these analyses ignore the stagflation experience of the 1970s, in which inflation was high even with "slack" markets and little "demand," and "expectations" moved quickly. They ignore the experience of hyperinflations and currency collapses, which happen in economies well below "potential." The Phillips curve does shift, and a fiscal inflation may well correspond to a shift, not a movement along that curve, and there may be very little the central bank can do about it.

\section{Conclusion}

The government debt valuation equation

$$
\frac{M_{t}+B_{t}}{P_{t}}=E_{t} \int_{\tau=0}^{\infty} \frac{1}{R_{t, t+\tau}} s_{t+\tau} d \tau
$$

is at the center of macroeconomic events right now, from understanding the recession, to stimulus, to monetary policy, to the inflation/deflation debate, to the future of the Euro. 
Will we get inflation? The scenario leading to inflation starts with poor growth, possibly reinforced by to larger government distortions, higher tax rates, and policy uncertainty. Lower growth is the single most important negative influence on the Federal budget. Then, the government may have to make good on its many credit guarantees. A wave of sovereign (Greece), semi-sovreign (California) and private (pension funds, mortgages) bailouts may pave the way. A failure to resolve entitlement programs that everyone sees lead to unsustainable deficits will not help.

When investors see that path coming, they will quite suddenly try to sell government debt and dollar-denominated debt. We will see a rise in interest rates, reflecting expected inflation and a higher risk premium for U.S. government debt. The higher risk premium will exacerbate the inflationary decline in demand for U.S. debt. A substantial inflation will follow - and likely a "stagflation" not inflation associated with a boom. The interest rate rise and inflation can come long before the worst of the deficits and any monetization materialize. As with all forward-looking economics, no obvious piece of news will trigger these events. Officials may rail at "markets" and "speculators." Economists and the Fed may scratch their heads at the sudden "loss of anchoring" or "Phillips curve shift."

This is a scenario, not a forecast. Whether it happens depends on the actions of our public officials, which are very hard to forecast.

In the meantime, as I have outlined, the intellectual landscape for the analysis of monetary and fiscal policy is changed deeply by a world in which fiscal issues crystallized in (18) exert stronger influence on the advanced economies than they have for generations.

\section{References}

Ashcraft, Adam, Nicolae Garleanu, and Lasse H. Pedersen, 2010, "Two Monetary Tools: Interest Rates and Haircuts," NBER Macroeconomics Annual, forthcoming.

Bernanke, Ben S., 2009a, Financial Reform to Address Systemic Risk, March 102009 , http://www.federalreserve.gov/newsevents/speech/bernanke20090310a.htm

Bernanke, Ben S., 2009b, June 3 Testimony, http://www.federalreserve.gov/newsevents/testimony/bernanke20090603a.htm

Bernanke, Ben S., 2009c, Testimony on the Semiannual Monetary Policy Report to the Congress, Before the Committee on Financial Services, U.S. House of Representatives, Washington, D.C. July 21, 2009 http://federalreserve.gov/newsevents/testimony/bernanke20090721a.htm

Bernanke, Ben S., 2010a, "Federal Reserve's Exit Strategy" http://federalreserve.gov/newsevents/testimony/bernanke20100210a.htm, http://federalreserve.gov/newsevents/testimony/bernanke20100325a.htm

Bernanke, Ben S., 2010b, "Testimony on the Semiannual Monetary Policy Report to the Congress, Before the Committee on Financial Services, U.S. House of Representatives, 
Washington, D.C."

http://federalreserve.gov/newsevents/testimony/bernanke20100224a.htm

Bernanke, Ben S., 2010c, "Ahieving Fiscal Sustainability," Remarks to the National Commission on Fiscal Responsibility and Reform, Washington, D.C. April 27, 2010, http://www.federalreserve.gov/newsevents/speech/bernanke20100427a.htm

Burnside, C., Eichenbaum, M. and Rebelo, S., 2001, "Prospective Deficits and the Asian Currency Crisis." Journal of Political Economy 109, 1155-98.

Burnside, Craig, Martin Eichenbaum and Sergio Rebelo, 2006, "Government Finance in the Wake of Currency Crises," Journal of Monetary Economics 53, 401-440.

Campbell, John Y., and Robert J. Shiller, 1988, "The Dividend-Price Ratio and Expectations of Future Dividends and Discount Factors," Review of Financial Studies, 1, $195-228$.

Cha, Ariana Eunjung, 2009, "Geithner Tells China Its Dollar Assets Are Safe" Washington Post Foreign Service, June 1, 2009, http://www.washingtonpost.com/wp-dyn/content/article/2009/06/01/AR2009060101784.html

Christiano, Lawrence, Martin Eichenbaum, and Sergio Rebelo, 2010, "When is the Government Spending Multiplier Large?" Manuscript, Northwestern University.

Cochrane, John H., 1992, "Explaining the Variance of Price-Dividend Ratios," Review of Financial Studies 5,243-80.

Cochrane, John H., 1988, "A Frictionless model of U.S. Inflation," in Ben S. Bernanke and Julio J. Rotemberg, eds., NBER Macroeconomics Annual 1998 Cambridge MA: MIT press, p. 323-384.

Cochrane, John H., 2001, "Long Term Debt and Optimal Policy in the Fiscal Theory of the Price Level," Econometrica 69, 69-116.

Cochrane, John H., 2005, "Money as Stock," Journal of Monetary Economics 52:3, 501528.

Cochrane, John H., 2007, "Inflation Determination with Taylor Rules: A Critical Review," Manuscript, University of Chicago.

Cochrane, John H., 2008, "The Dog That Did Not Bark: A Defense of Return Predictability," Review of Financial Studies 21, 1533-1575.

Cochrane, John H., 2010, "The Government Debt Valuation Equation. An Appendix to "Understanding Policy"' http://faculty.chicagobooth.edu/john.cochrane/research/Papers/

Congressional Budget Office, 2009, "A Preliminary Analysis of the President's Budget and an Update of CBO's Budget and Economic Outlook," http://www.cbo.gov/ftpdocs/100xx/doc10014/Summary.4.1.shtml 
Council of Economic Advisers, 2009, "The Economic Case for Health Care Reform" http://www.whitehouse.gov/assets/documents/CEA_Health_Care_Report.pdf

Duffie, Darrell, 2010, "The Failure Mechanics of Dealer Banks," Journal of Economic Perspectives $24,51-72$.

Elmendorf, Doug, 2009, "The Budget and Economic Outlook," September 2009 presentation to the National Economists Club, http://www.cbo.gov/doc.cfm?index=10624\&type=1

Federal Reserve, 2010, "Semiannual Monetary Policy Report to the Congress," February 24,2010 http://federalreserve.gov/monetarypolicy/mpr_20100224_part1.htm. February 24.

Feldstein, Martin, 2009, "Inflation is Looming on America's Horizon," Financial Times, April 19, http://belfercenter.ksg.harvard.edu/publication/18990/ inflation_is_looming_on_americas_horizon.html

Ferguson, Niall, 2009, "History Lesson for Economists in Thrall to Keynes" Financial Times, May 29 2009, http://www.ft.com/cms/s/0/a635d12c-4c7c-11de-a6c5-00144feabdc0.html

Gorton, Gary B., and Andrew Metrick, 2009, "Haircuts" NBER Working Paper 15273.

Gorton, Gary B., and Andrew Metrick, 2009b, "Securitized Banking and the Run on Repo," NBER Working Paper No. 15223.

Graham, Jed, 2010, “ Debt Shock May Hit In 2018, Maybe As Soon As 2013," Investor's Business Daily May 6, 2010, p. A01.

Hilsentrath, Jon, 2010, "Inflation Fears Cut Two Ways at the Fed" Wall Street Journal April 52010.

Krishnamurthy, Arvind and Annette Vissing-Jorgenson, 2008, "The Aggregate Demand for Treasury Debt," Manuscript, Northwestern University.

Krugman, Paul, 2009, "The Big Inflation Scare" New York Times May 282009 http://www.nytimes.com/2009/05/29/opinion/29krugman.html

Leeper, Eric, 1991, 'Equilibria Under 'Active' and 'Passive' Monetary and Fiscal Policies," Journal of Monetary Economics 27, 129-147.

Laffer, Arthur, 2009, "Get Ready for Inflation and Higher Interest Rates "Wall Street Journal, June 11, 2009, http://online.wsj.com/article/SB124458888993599879.html

Miller, Rich, 2009, "U.S. Needs More Inflation to Speed Recovery, Say Mankiw, Rogoff," Bloomberg.com May 19 2009, http://www.bloomberg.com/apps/news?pid=20601083\&sid=auyuQlA1lRV8 
Orszag, Peter R., 2008, "Letter to Representative Paul Ryan (R-WI)," May 19, 2008, http://www.cbo.gov/ftpdocs/92xx/doc9216/.

Piergallini, Alessandro, and Rodano, Giorgio, 2009, "Public Debt, Distortionary Taxation, and Monetary Policy," Manuscript, University of Rome.

Pittman, Mark, and Bob Ivry, 2009, "Financial Rescue Nears GDP as Pledges Top $\$ 12.8$ Trillion (Update1)" Bloomberg.com March 31 2009, http://www.bloomberg.com/apps/news?pid=20601087\&sid=armOzfkwtCA4

Novy-Marx, Robert, and Joshua D. Rauh, 2009, "The Liabilities and Risks of StateSponsored Pension Plans," Journal of Economic Perspectives, 23(4): 191-210, DOI:10.1257/jep.23.4.191.

Rey, Helene, and Pierre-Olivier Gourinchas, 2007, "International Financial Adjustment," Journal of Political Economy, 115, 665-703.

Romer, Christina and David Bernstein, 2009, "The Job Impact of the American Recovery and Reinvestment Plan," http://otrans.3cdn.net/45593e8ecbd339d074_13m6bt1te.pdf

Samuelson, Robert J., 2008, The Great Inflation and its Aftermath, New York: Random House.

Sargent, Thomas J., 1992, Rational Expectations and Inflation, New York: Harper and Row, Second edition.

Sargent, Thomas J., 1999, The Conquest of American Inflation, Princeton: Princeton University Press

Sargent, Thomas J. and Neil Wallace, 1981,"Some Unpleasant Monetarist Arithmetic," Federal Reserve Bank of Minneapolis Quarterly Review, 5:3, Fall 1981, 1-17.

Satow, Julie, 2009, http://www.nysun.com/business/anna-schwartz-the-fed-is-inviting-inflation/70958/

Taylor, John, 2009b, "Empirically Evaluating Economic Policy in Real Time," NBER Reporter 2009 Number 3, www.nber.org/reporter.

Trabandt, Mathias, and Harald Uhlig, 2009, "How Far Are We From the Slippery Slope? The Laffer Curve Revisited," NBER Working Paper 15343.

Uhlig, Harald, 2010, "Some Fiscal Calculus," Manuscript, University of Chicago.

Woodford, Michael, 2003, Interest and Prices: Foundations of a Theory of Monetary Policy, Princeton: Princeton University Press. 